

\section{DISCLAIMER}

This report was prepared as an account of work sponsored by an agency of the United States Government. Neither the United States Government nor any agency Thereof, nor any of their employees, makes any warranty, express or implied, or assumes any legal liability or responsibility for the accuracy, completeness, or usefulness of any information, apparatus, product, or process disclosed, or represents that its use would not infringe privately owned rights. Reference herein to any specific commercial product, process, or service by trade name, trademark, manufacturer, or otherwise does not necessarily constitute or imply its endorsement, recommendation, or favoring by the United States Government or any agency thereof. The views and opinions of authors expressed herein do not necessarily state or reflect those of the United States Government or any agency thereof. 


\section{DISCLAIMER}

Portions of this document may be illegible in electronic image products. Images are produced from the best available original document. 
Issued by Sandia Laboratories, operated for the United States Energy Research \& Development Administration by Sandia Corporation.

\section{NOTICE}

This report was prepared as an account of work sponsored by the United States Government. Neither the United States nor the United States Energy Research \& Development Administration, nor any of their employees, nor any of their contractors, subcontractors, or their employees, makes any warranty, express or implied, or assumes any legal liability or responsibility for the accuracy, completeness or usefulness of any information, apparatus, product or process disclosed, or represents that its use would not infringe privately owned rights.

Printed in the United States of America

Available from

National Technical Information Service

U. S. Department of Commerce

5285 Port Royal Road

Springfield, VA 22161

Price: Printed Copy $\$ 4.50$; Microfiche $\$ 3.00$ 
SAND77-0690

Unlimited Release

Printed May 1977

SOLAR TOTAL ENERGY SYSTEM TEST FACILITY

OPERATIONAL PHASE TEST PLAN

K. D. McAllister

$\mathrm{EG} \& \mathrm{G}$, Inc.

Siegfried Thunborg

Solar Total Energy System Test Facility Division 5712

Sandia Laboratories

A.lbuquerque, NM 871.15

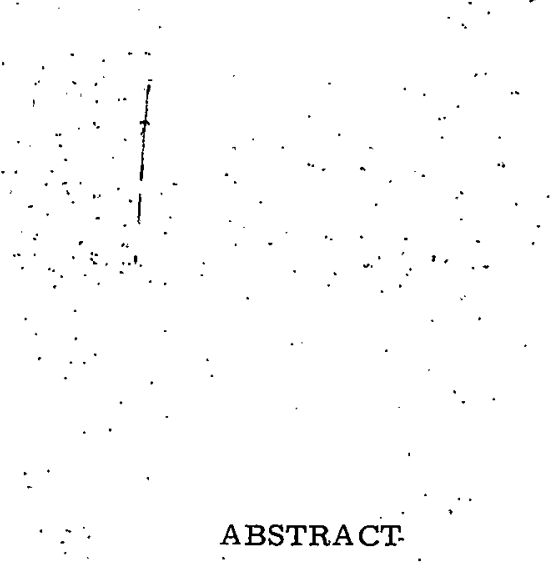

This report wotice

This report was prepared as an account of work the United She United States Government. Neither Research and Development Ad Uninied States Energy their employees, nor any of their, nor any or subcontractors, or their employees, makes any warranty, express or implied, or assumes any legy las ility or responsibility for the accuracy, completeness process diss of any information, apparat us, product of infringe privately ouned rigents that its use would no

\section{ABSTRACT}

This report specifies the testing which will be pcrformed on the solar-to-electric components of the Solar Total Energy System Test Facility. Objectives are defined and test procedures described.

\section{MASTER}

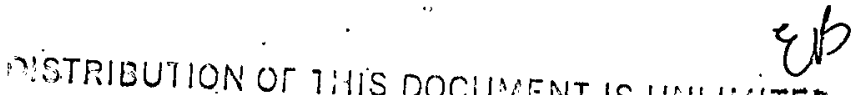

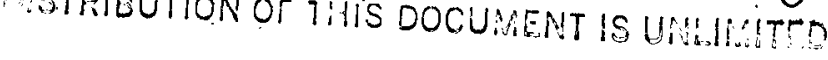




\section{CONTENTS}

1. INTRODUCTION

1.1 Background

1.2 Phase IV-A Objectives

1.3 Program Approach

2. COLLECTOR SUBSYSTEM TESTS . . 13

2.1 Performance $\quad 13$

2.1.1 Automatic Defocus 13

2.1.2 Reflector/Structure Evaluation (Aperture Test) 14

2.1.3 Focaí Position 16

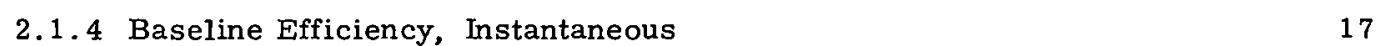

2.1.5 Baseline Efficiency, Daily 18

2.1.6 Receiver Tube Loss Rate 18

2.1.7 Analog Tracker Evaluation $\quad \cdot \quad 19$

2.1.8 Computer/Encoder Tracker Evaluation $\quad$ " 19

2.1.9 Laser Evaluation of Reflector/Structure $\quad \cdot 20$

2.2 Environmental 21

2.2.1 Dirt Effects 21

2.2.2 Aging Effects $\quad 21$

2.2.3 Structure Twist · ' ‘ ' ' 22

2.2.4 Long-Term Distortion of Structure $\quad 22$

2.3 Control $\quad \cdots \cdot \cdot r \cdot 22$

2.3.1 Mixing Contrn! $\quad 22$

2.3.1.1 Morning Startup $\quad \cdots \quad 22$

2.3.1.2 Noon Startup $\quad . \quad \cdot \quad \cdot \quad \cdot 23$

2.3.2 Buffer Control . . $\quad 24$

2.3.2.1 Morning Startup 24

2.3.2.2 Noon Startup $\quad \cdot \quad 24$

2.3.3 Effects of Two Parallel Rows of Collectors on Control 25

$\begin{array}{ll}2.4 \text { Miscellaneous } & 26\end{array}$

2.4.1 Field Pipe Heat Loss $\quad 26$

2.4.2 Overnight Field Heat Loss 28

2.4.3 Daily Pump Power Versus Energy Collected 29

3. STORAGE SUBSYSTEM 30

$\begin{array}{lll}3.1 & \text { Thermocline Stahility } & 30\end{array}$

$\begin{array}{lll}3.1 .1 & \text { Static Stability } & 30\end{array}$ 


\section{CONTENTS (con't)}

3.1.2 Dynamic Stability

3.1.3 Long-Term Stability 31

3.1.4 Sensitivity to Out-of-Tolerance Fluids 32

3.1.5 Liquid Level Versus Temperature 33

3.2 Thermal Losses and Mass Effects 34

3.2.1 Insulation Thermal Evaluation $\quad \cdot \quad 34$

$\begin{array}{ll}3.3 \text { Control } & 35\end{array}$

3.3.1 Automatic Cooler Mode Operation

3.3.2 Automatic Heater On/Off Operation . . . 36

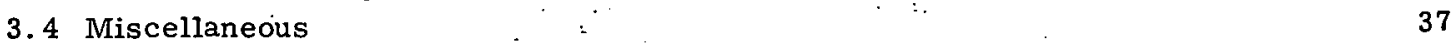

3.4.1 Maximum Withdrawal Rate From Storage $\quad . \cdots$

4. HEATER BOILER AND ORC SUBSYSTEMI

4.1 Performance

4.1.1 Baseline ORC Performance $\quad 39$

4.1.2 Transient ORC Performance - Heater Boiler Mode 40

4.1.3 Transient ORC Performance - Storage Boiler Mode 41

4. 1.4 Maximum ORC Output $\quad 42$

4.1.5 Out-of-Tolerance Temperature E'ffects 42

4.2 Control

4.2.1 Heater Control Evaluation 43

1.3.2 ORG Control Evaluation $\quad 45$

4.2.3 Automatic Switching 46

$\begin{array}{ll}\text { 1.3 Miscellaneous } & 47\end{array}$

4.3.1 Boiler Piping Steady-State Losses $\quad 47$

4.3.2 Boiler Thermal Mass 48

$\begin{array}{lll}4.3 .3 & \text { Pumping Losses . } & 48\end{array}$

5. CONDENSER AND COOIMNG-WATER FLUID IIAINDING SUBSYSTFM

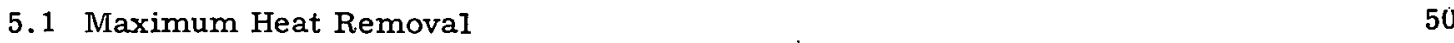




\section{Figure}

1 C ascaded Solar Total Energy System

2 Solar Total Energy Program Milestones

3 Sihematic of Aperature Test

4 Schematic of Insulation Thermal Test Setup

5 Schematic of Auto Cooler Mode Operation

6 Heater/ORC Turbine Safety Controls $\underline{\text { Page }}$

10

11

15

35

36

44 


\title{
SOLAR TOTAL ENERGY SYSTEM TEST FACILITY OPERATIONAL PHASE TEST PLAN
}

\author{
1. Introduction
}

\subsection{Background}

Potential uses of solar energy have been subjects of studies, both theoretical and experimental, at Sandia Laboratories since 1972. An outgrowth of these studies has been the Solar Total Energy Project. The primary objective of the Sandia Solar Total Energy Project is to determine and demonstrate the feasibility of solar total energy systems for a variety of sites and applications. In support of this overall project objective, a Solar Total Energy System Test Facility is being developed. This facility will be used as an engineering evaluation center and testbed for further development of individual components or other solar energy systems.

The Sandia Solar Total Energy System is depicted in Figure 1. This system is designed to operate as follows: A heat transfer fluid is heated in receiver tubes of solar collectors by reflected and focused solar radiation. This heated fluid is stored in a high temperature (up to $310^{\circ} \mathrm{C}$ ) storage tank. Fluid is then pumped from this storage tank and fed through a heat exchanger to produce superheated toluene vapor, which in turn mechanically drives an Organic Rankine Cycle (ORC) turbine/generator. The output of the turbinc/generator is used to provide electrical power. Waste heat from the turbine is dissipated from the turbine condenser by means of a glycol coolant, which is stored in a low, temperature (up to $88^{\circ} \mathrm{C}$ ) storage tank. This low temperature tank is the energy source for a separate heating, air conditioning, and hot water system.

The Solar Total Energy Program is divided into five phases. The first three phases were primarily analytical, and the last two phases are to be primarily experimental. The Solar Total Energy Program schedules are shown in Figure 2.

Phase IV-A marks the transition frnm analytical and design eftort to the hardware and construction effort. This phase consists of the fabrication and testing of approximately $25 \%$ of the high temperature solar collecturs, the storage portion of the system, and $100 \%$ of the turbine generator and boiler portion of the system. Therefore, Phase IV-A concerns only the portion of the entire Solar Total Energy System dealing with the solar to electrical energy conversion. 


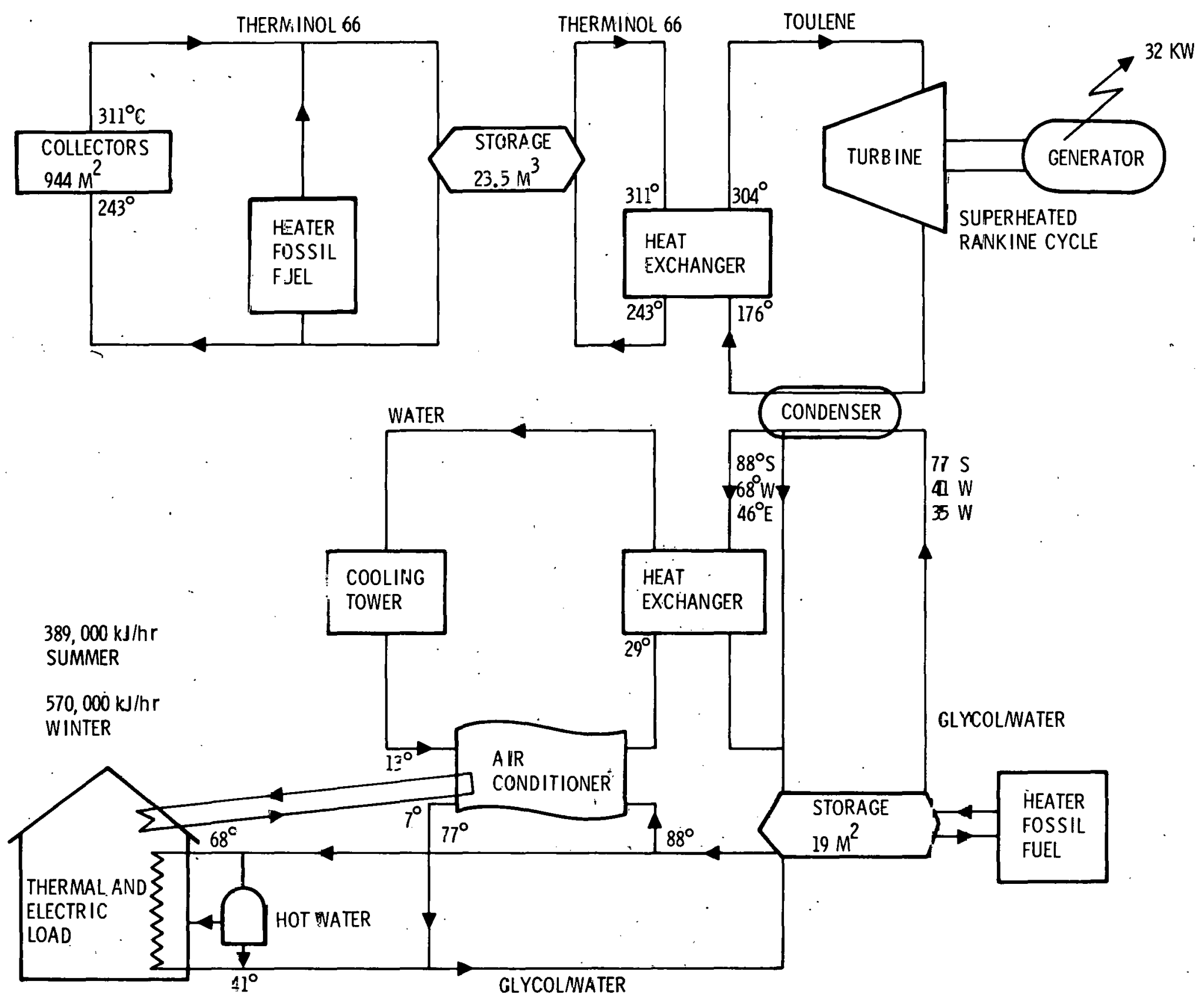

Figure 1. Cascaded Solar Total Energy System 
SOLAR TOTAL ENERGY PFOGRAM

Fiscal Year

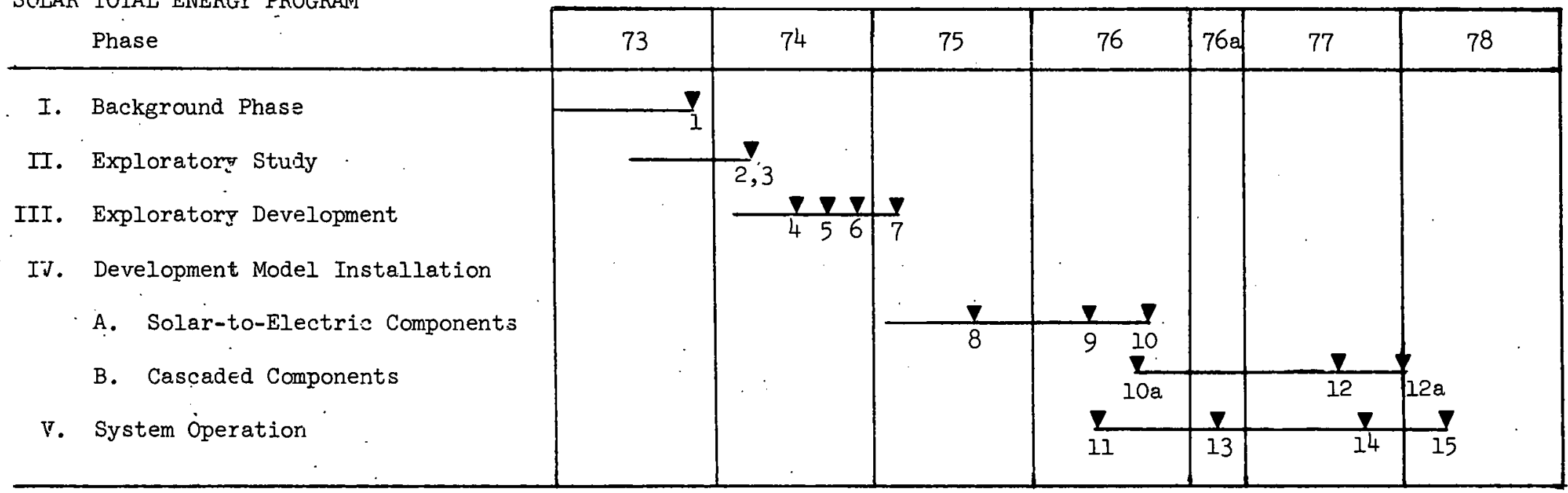

\section{Milestones :}

1. Completion of Phase I

2. Preliminary system design complete

3. Economic evaluation complete

4. Collector evaluation facility complete

5. System analysis program (SOLSYS) operational

6. Baseline system design complete

7. Phase IV-A proposal submitted

8. Phase IV-A design freeze

9. Partial collector field, storage, and turbine-generator test bed complete

10. Phase IV-A complete, system 100 jercent operational

10a. Subcontracts for collector field subsystems placed

11. Initial operation of partial Solar Total Energy System Test Facility

12. Low-temperature components of Solar Total Energy System Test Facility installed.

12a. Subcontracted collector field subsystems completed

13. System analysis program (SOLSYS) refined and revalidated

14. Demonstration of Solar Project Building

15. Operation of complete Solar Total Energy System Test Facility

Figure 2. Solar Total Energy Program Milestones 


\subsection{Phase IV-A Objectives}

Phase IV-A consists of the fabrication, installation, and operational checkout of a $200 \mathrm{~m}^{2}$ collector field, a temporary mid-sized high-temperature storage tank, a $32 \mathrm{~kW}$ Organic Rankine Cycle turbine/generator with its fluid-to-toluene heat exchanger, an instrumentation and control subsystem, a cooling tower, the turbine and control building, and all necessary pumps and fluid loops to interconnect systems.

\subsection{Program Approach}

To support the testbed concept of the Solar Total System Energy Test Facility, a gencral test plan and schedule lias leen devclopcd. This document rnntains specific test plans tor the Phase IV-A system. The Phase IV-A system has been divided into subsystems as follows:

1. Collector Subsystem

2. Storage Subsystem

3. Heatcr, Boiler, and ORC. Subsystem

4. Condenser and Cooling-Water Fluid Handling Subsystem.

This document is arranged with a major section devoted to each of the subsystems. Collector Subsystem Tests are in Chapter 2, Storage Subsystem Tests are in Chapter 3, Heater, Boiler and ORC Subsystem Tests are in Chapter 4, and Condenser and Cooling-Water Fluid Handling Tests are in Chapter 5. 


\section{COLLECTOR SUBSYSTEM TESTS}

\subsection{Performance}

This section of the Collector Subsystem Tests deals with performance of this subsystem.

\subsubsection{Automatic Defocus}

TEST OBJECTIVE: To demonstrate proper operation of the emergency defocus safety system under simulated actual operating conditions.

TEST DESCRIPTION: There are six potential malfunctions which could cause damage to the receiver tubes if the collectors are left in focus. To prevent this damage from occuring, the collector tracking system has been designed with an emergency safety defocus capability which is triggered by any one of the six malfunctions. Should one or more of these malfunctions occur, the emergency defocus system will drive all the collectors away from the sun until a limit switch is activated which cuts power to the drive motor. The collectors will be driven to the north in the wintertime, to the south in the summertime. The six identified malfunctions which actuate the emergency defocus capability are:

1. Tube Overtemperature. Two thermocouples have been placed on the hottest part of each receiver tube. If tube temperature should exceed a preset level, a controller is tripped which activates the defocus system. When the defocus system is activated in this manner the collector field fluid transfer pump will come on at full speed and stay on until it is manually turned off.

2. Overexpansion of Receiver tubes. Limit switches have been placed at the expansion ends of each of the receiver tubes. If a receiver tube expands to the point where the limit switch is triggered, the collectors will be defocused and the collector field fluid transfer pump will come on at full speed. The limit switches are set to trigger at a tube temperature of $625^{\circ} \mathrm{F}$ to $650^{\circ} \mathrm{F}$.

3. Loss of 'l'racker Power. If ac power to the tracker system is lost, the main power relay will open and actuate a battery pack which will then be connected directly to the motor and will drive the collectors to the limit switches.

4. Loss of Valve Control Rack Power. If power is lost to the valve control rack (which controls all of the electrically controlled pneumatic valves), and to the over-temperature controller (which activates the emergency defocus system), 
the collectors will be defocused and the collector fluid pump will comc on at full speed.

5. Loss of Computer Power. When ac power to the computer is lost the collectors will be defocused.

6. Loss of Fluid Flow. If the output of the flow meter (which measures the flow of heat transfer fluid) drops to a designated preset trigger level, the collectors will be defocused. In this failure mode the fluid-transfer-pump is not caused to run full speed, siice it is part of the efferter system, and possibly the cause of the problen.

TEST CONDITIONS: There are no environmental or solar requirements for successful completion of this test.

It is required that ac power be available to the tracker motors, to the computer, and to the valve control rack. It is also required that the collector tracker system be functioning properly.

Each of the six malfunctions is to be simulated by manually tripping limit switches, by pulling ac power cords, or by entering false preset trigger levels.

DATA REQUIREMENTS: 'I'he test englrieer's lug iuting the rozotions of the emergency defocus system to the simulated malfunction.

\section{1 .2 Reflector/Structure Evaluation (Aperture Test)}

TEST OBJECTIVES: To determine the mirror slope error as a function of location for each of the four parabolic troughs. A secondary objective is to optimize the location of the receiver tubes in the focal lines.

TEST DESCRIPTION: A 12-foot slit aperture made of $2^{\prime \prime} \times 6^{\prime \prime}$ lumber and opaque polyethylene film will be utilized for this test. Schematic application of this aperture is shown in a cross section in Flgure 3. Tigurca $3(\mathrm{a})$ and $3(\mathrm{~h})$ show the slit at two positions with the resultant light beam focused on the receiver tube. Figure 3 (c) shows the effect of an exaggerated local discontinuity. As the slit aperture is slowly moved from the right-hand rim to left-hand rim, a narrow beam of light slowly rotates from the three o'clock on the rccciver tube to the nine o'clock position. 


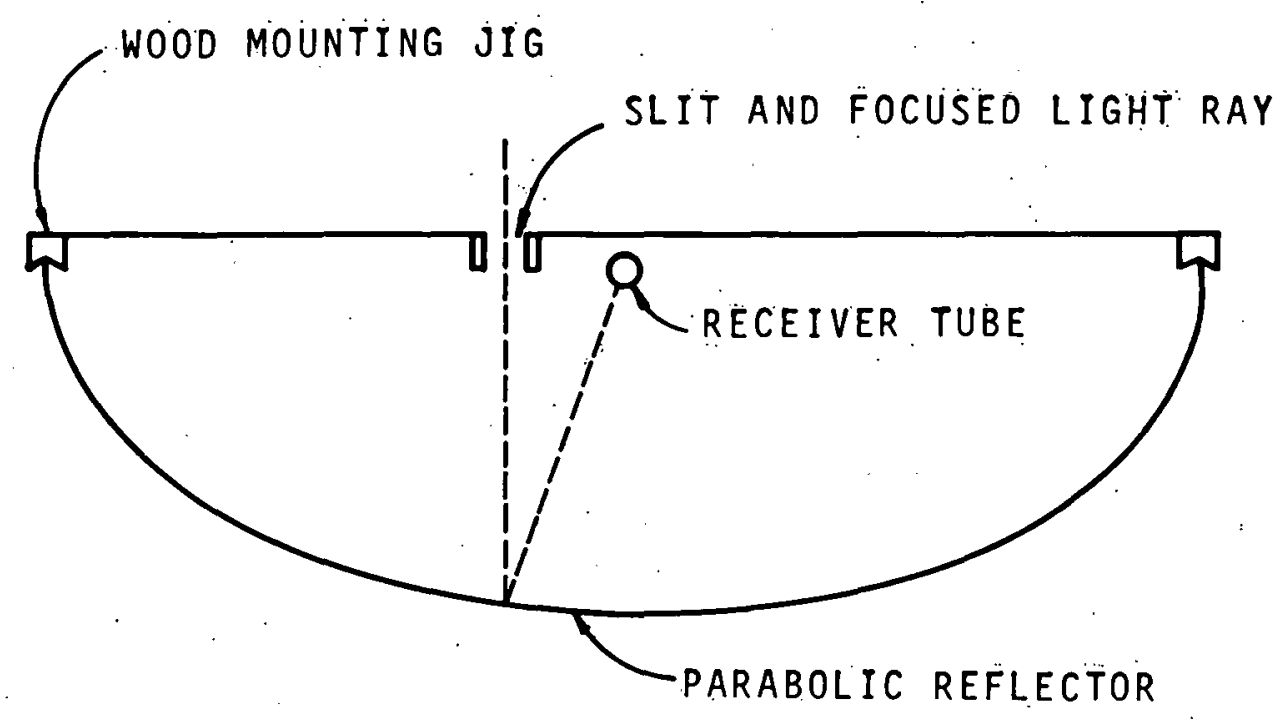

(a)

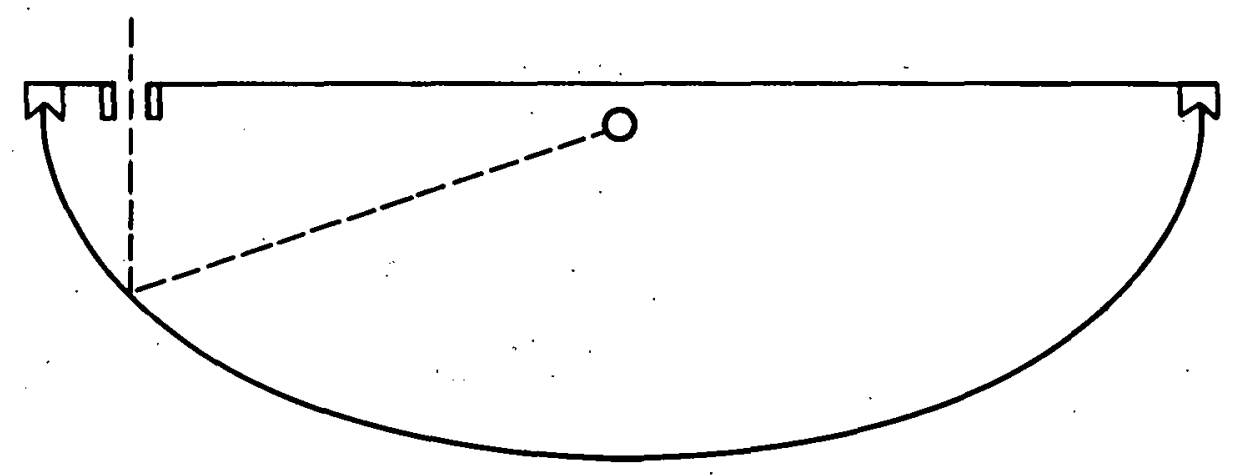

(b)

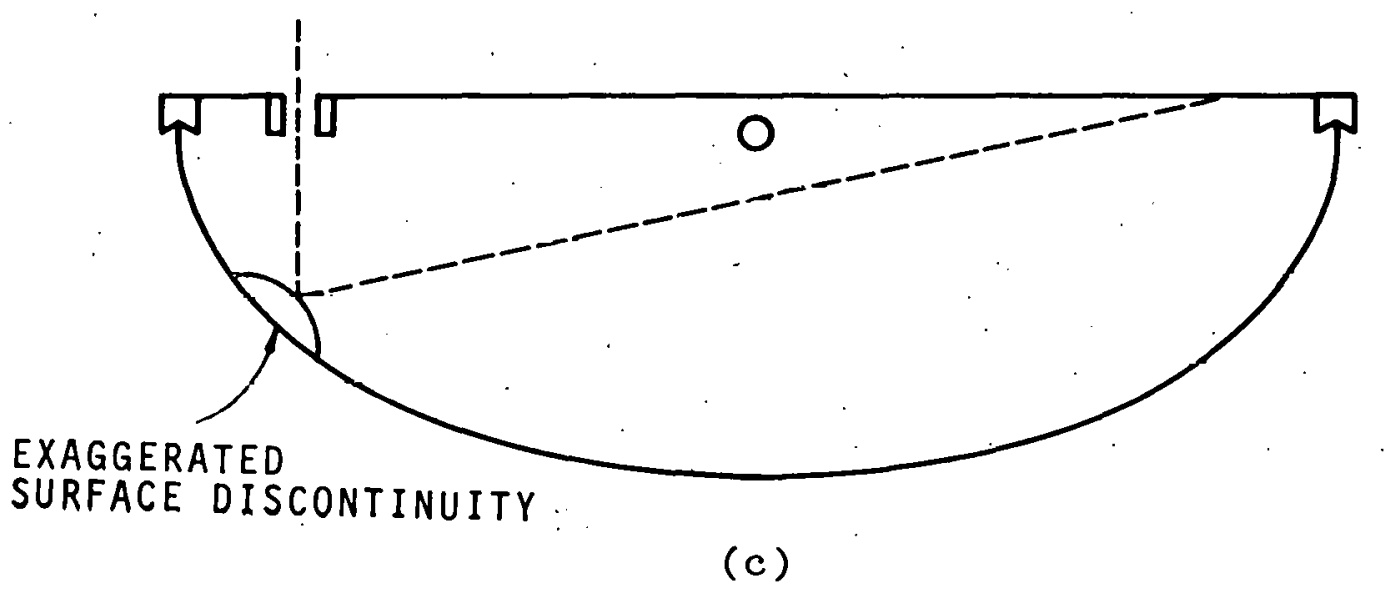

Figure 3. Schematic of Aperture Test 
The test procedure will be: (1) to install the aperture slit on each 12-ft unit on each bank of 5 collector panels; (2) to focus the tracker system; (3) to slowly move the slit from one rim to the other while noting the location and quality of the focused beam on the receiver tube (particular attention must be given to the areas within 18 inches of each rim and within 18 inches of each side of the collector tube); (4) to align the receiver tube as required to gather the maximum amount of focused energy. Repeat steps 3 and 4 as necessary.

TEST CONDITIONS: The tracker system must be properly aligned and functioning. Cooled heat transfer fluid must be circulating through the tubes to remove excess heat, as the maximum temperature allowed is $600^{\circ} \mathrm{F}$. Bright sunlight and light winds ( $\$ 15 \mathrm{mph}$ ) are also required to complete this test.

DATA REQUIREMENTS: The detailed notes, logs and observations of the responsible project engineer and the system operators.

\subsubsection{Focal Pósition}

TEST OBJECTIVE: To determine for each of the four collector panels the optimum correction factor to the true solar pointing angle, which maximizes collector efficiency.

TEST DESCRIPTION: The northeast quadrant collector shall be focused manually using the operator's estimate for best focus. The collector shall then be defocused to the north approximately one degree. The collector inlet temperature, outlet temperature, and efficiency shall then be recorded. 'Ihe collector shall then be stepped in one-tenth degree increments through the estimated best-focus position on through to one degree south of focus. At each increment the inlet and outlet temperature and efficiency shall be recorded after a steady-state is established. The same procedure shall then be repeated on the southeast, southwest and northwest quadrant collectors. The best focal position then, is that position which maximizes temperature increase and efficiency of the collector as a function of angular correction to the calculated solar pointing angle.

TEST CONDITIONS: This test should be run on a clear, sunny day around noontime. If feasible, the test should also be run in the early morning (as soon as accurate solar tracking is possible) and late in the afternoon. The optimum focal position may change as a function of time during the course of the day.

\section{DATA REQUIREMENTS:}

1. Shaft encoder position

2. Indicated degree error

3. Temperature in

4. Temperature out 
5. Flow rate

6. Efficiency

7. Time of day and date

\subsubsection{Baseline Efficiency, Instantaneous}

TEST OBJECTIVES: To measure the collector efficiency (i.e., the total heat energy collected as a percentage of total direct insolation on the reflectors) under varying operating conditions.

TEST DESCRIPTION: Factors which can influence the efficiency of the collectors include solar intensity, dust on the reflectors, vacuum in the glass collector tube shield, wind, flow rate, initial fluid temperature, etc. The objective of this test is to repeat measurements of instantanous baseline efficiency as required, since all of the above conditions vary over a period of time. Those conditions under the control of the operator (e.g., flow rate and temperature), shall be varied in a controlled manner to simulate all possible realistic operating conditions. Thus the baseline efficiency should be measured as a function of fluid temperature by starting the test with a blending tank full of cold oil $\left(470^{\circ} \mathrm{F}\right)$, and slowly bringing the temperature up to $600^{\circ} \mathrm{F}$. The effects of environmental conditions such as wind and solar intensity will be evaluated by repeating instantaneous baseline efficiency measurements over a period of time when, in the judgment of the operator, the prevailing conditions are unusual, new, or different.

TEST CONDITIONS: Since the objective of this test is to measure the baseline efficiency under varying environmental and operating conditions, it is impossible to list all possible variations of these conditions. As a minimum, the following conditions shall be investigated by performing instantaneous baseline efficiency measurements as thcse conditions are varied over time:

1. Wind

2. Flow rate

3. Fluid temperature

4. Angle of solar incidents (i.e. time of day)

5. Solar intensity

a. Varying conditions of overcast

b. Varying times of year

6. Vacuum

7. Air temperature

DATA REQUIREMENTS: Total heat collected is determined by measuring the temperature rise, flow rate, and average temperature of fluid as it passes through the collectors. Total direct insolation is measured directly by a pyroheliometer. All of the above data is automatically sampled by the system control computer and instantaneous efficiency is automatically calculated and printed out. 


\subsubsection{Baseline Efficiency, Daily}

TEST OBJECTIVE: To measure the average collector efficiency throughout an operating day and to repeat this test for varying climatic conditions.

TEST DESCRIPTION: This test would consist of a complete day's operation of the solar collectors with the instantaneous operating efficiency sampled frequently throughout the day, and the average day's efficiency calculated from a weighted average of instantaneous efficiency. This test should be repeated several times at different times of the year and in varying climatic conditions including very cold days, very warm days, extremcly clear, sunny days, and partially cloudy days. This test should also be repcated using the analog volar tracker and the digital solar tracker. The digital tracker can begin tracking the sun earlier in the morning and later in the evening, thereby allowing evaluation of efficiency at a wider range of impingement angles.

TEST CONDITIONS: This test requires proper operation of the solar tracking deviscs, the collector field heat-transfer pump, and the collector field data-acquisition system. Inasmuch as this test is to evaluate efficiency in various climatic conditions, the environmental conditions specified in the previous paragraph are to be recorded and evaluated. Opcration of the ORC or the oil cooler will be required to remove excess heat collected during the course of the day.

DATA REQUIREMENTS: The collector field data printout will be required once every ten minutes for the duration of these tests. The calculated collector efficiency is of primary interest, however all the collector field performance data will be required. Weather data during the course of the test are also required. This data can be provided by the facility operator in the form of notes and ohservations in the operator's log, or from recordings laken from the solar test facility weather station. Weather parameters of import include tempcrature, wind, humidity and cloud coverage.

\subsubsection{Receiver Tube Loss Rate}

TEST OBJECTIVE: To determine the "no sun" loss through or from the receiver tubes.

TE3T DLECHIFTION: Tw , simply circulate hot fluid through the receiver tube and record the flow rate, temperature in, and temperature out. Computation of the difference of input and output temperature, with respect to flow rate, will determine heat loss. This test will consist of circulating hot fluid at various temperatures through the receiver tubes and recordiny llese paramctcre. This test shall be run at temperatures starting at $470^{\circ} \mathrm{F}$ and proceeding to $605^{\circ} \mathrm{F}$ in 25 -degree increments.

TEST CONDITIONS: There are no specific environmental conditions required for this test. This test shall be run with collectors defocused. The test shall be started with $470^{\circ} \mathrm{F}$ fluid from the storage tank. To increase the temperature of the fluid for the successive tests, the fossil-fuel heater shall be used. 
DATA REQUIREMENTS: Temperature in, temperature out, and temperature decrease in each of the four collector tubes, the flow rate through the collector tubes, and the ambient temperature and wind velocity.

\subsubsection{Analog Tracker Evaluation}

TEST OBJECTIVE: To evaluate the accuracy of the analog solar tracker mounted on the collector tubes. Inasmuch as modifications and improvements are continually being made to the analog trackers, this test shall be repeated after every modification to the tracker.

TEST DESCRIPTION: The test should start as soon after sunrise as the tracker will provide adequate focusing. The test shall consist of allowing the analog trackers to maintain focus while recording the angular error between actual collector pointing angles and the known solar vector pointing angle. In addition, the instantaneous efficiency of the collectors shall be recorded.

This efficiency shall then be compared to the efficiency recorded during the optimum focal position testing for those times of day in which comparable data is available.

TEST CONDITIONS: This test must be performed on a clear, sunny day. The teat will be perfurmed with the solar collectors being controlled by the analog optical tracker. All the collector system data acquisition sensors must be functioning for this test.

\section{DATA REQUIREMENTS:}

1. Temperature into each collector

2. Temperature out of each collector

3. Instantaneuus efficiency

4. Solar pointing angle from the digital encoder

5. Angle error

6. Time of day

\subsubsection{Computer/ Bncüder Tracker Evaluation}

TEST OBJECTIVE: To determine the accuracy which the computer/encoder can be used to maintain optimum focal position.

TEST DESCRIPTION: This test would consist of two parts. First an inclinumeter is used to compare the angle of the collectors with that of the encoder. This comparison is made at each $15^{\circ}$ angle of travel of the collector from suuth to north, and north to south. These comparisons and any differences can be programmed into the computer software so optimum tracking.can be accomplished. Second, the computer/encoder will be utilized for tracking in an all-day test. The accuracy of the tracking will be checked at intervals of onc hour tu see lf optimum focal conditions are being maintained. 
TEST CONDITIONS: This test requires a precise inclinometer that can be read to within a one-minute angle. The software for the computer must provide encoder angle readout to within one minute. This will allow an accurate comparison of indicated angles. For the all-day accuracy check, there should be a clear sky. The data acquisition system, the collector drive system, and collector field fluid circulation pumps are required.

DATA REQUIREMENTS: The encoder angles read from the TTY screen and inclinometer angle from the instrument are needed for the first part of this test. These can be compared and a deviation determined. The second part requires the collector field data from the minicomputer to determine angular deviation from the encoder focal position and temperature input and output of the collector. A continual strip chart of input and output temperature differeulial is nccded, ao is a periodic check to determinc if the increase is a maximum mode. This clitck will be made by manually moving the collector one degree out of focus in each direction and observing the effect on temperature differential.

\subsubsection{Laser Evaluation of Reflector/Structure}

TEST OBJECTIVE: To determine how nearly each reflector approximates a perfect parabola, and how the reflector structure distorts from the parabolic shape with time.

-TEST DESCRIPTION AND CONDITIONS: This test requires use of a special laser-system set up. The parabolic shape of each collector trough is nearly that of a cylindrical arc with its center approximately 65 inches from the center of focus of the parabola. The laser rig should be arranged so that the liser beam, pointed at the collector, will reflect back from the parabolic trough to a detector near the laser. In a true cyllud lical are the lador boam unnitid reflect: back upon itself. There are differences in the cylindricnl arc and the parahola, but they should be close enough so that the difference between the transmitted and rcflected beam will be slight (Figure 3). This difference in the transmitted and calculated angles will be determined and used to evaluate the parabolic shape of the reflector structure. The entire reflector can bc tested by adjusting the angle of the laser to the horizontal and moving the laser rig parallcl to the center of the parabola for each angle. The only area impossible to test would be that area directly shadowed by the collector tube. This is a small area which should be the most accurate and suffer the least distortion with age.

Once the laser rig is constructed, it can be used periodically either to conduct a sample scan or to spot-test areas of concern. Thus the long term distortion of the reflector structure can be evaluated by using this same procedure and comparing results with past data.

One difficulty in setting up for this test is obtaining assurance that the laser rig is aligned with the center of the structure and the focal point of the parabola for the entire length of the collector, i.e., parallel with the focal plane of the reflector and also with the center of the collector tube. A technique to assure this alignment is being developed. 
DATA REQUIREMENTS: Recording of the angles between the incident and reflected laser beam (this should be standard for all points selected). This can be compared to the angle calculated for the difference between the parabolic shape and the cylindrical arc for distortion analyses.

\subsection{Environmental}

This section of the Collector Subsystem Tests deals with environmental effects on this subsystem.

\subsubsection{Dirt Effects}

TEST OBJECTIVE: To measure differences in the instantaneous collector efficiency brought about by a normal accumulation of dust and dirt.

TEST DESCRIPTION: Prior to starting this test the solar collectors will be allowed to accumulate a significant layer of dust and dirt. This test shall be repeated when the amount of dirt is, in the opinion of the operator, moderate, typical and heavy. When a dirt effects test is to be run, the operator shall measure the instantaneous efficiency in the "dirty" conditions. The collectors shall then be washed using the standard high-pressure detergent-spray technique followed by a deionized-water rinse. The instantaneous efficiency of the collectors will then be recorded.

TEST CONDITIONS: This test must be run on a sunny day so that comparative efficiency can be measured. It is required that the comparison between efficiency of the "clean" and "dirty" collectors be made utilizing data taken at approximately the same time of day, under approximately the same meteorological conditions, and using the same type of solar tracker.

DATA REQUIREMENTS: The collectors' instantancous cfficiency under the "clean" and "dirty" conditions and the operator's logs and notes concerning time of day, meterological conditions, and initial and ending conditions of the collectors.

\subsubsection{Aging Effects}

TEST OBJECTIVE: To determine the effect of aging on the collectors.

TEST DESCRIPTION: The aging effect tests shall consist of periodic repetitions of the structure twist test, the dirt effects test, the baseline efficiency test, and the laser evaluation test. Each of these tests shall be repeated quarterly or, at a minimum, semiannually.

TEST CONDITIONS; As described for cach of the Individual tests. 


\section{2 .3 Structure Twist}

TEST OBJECTIVE: To determine whether or not structure twist is being induced in to each of the four collector troughs. This structure twist is caused by differences in angular drive rates from end to end of the structure.

TEST DESCRIPTION: At the start of this test all collectors shall be racked over the furthermost north position until limit switches stop their movement. The position of the shaft encoders at either end of each of the four collector troughs shall be recorded. The troughs shall then be activated to move toward the south until they encounter limit switches on the southernmost point of travel. Again, the position of the shafl encodero at oach end of earh trough shall be recorded.

TEST CONDITIONS: There are no environmental conditions for this test. The only portions of the data acquisition system which are used, and therefore must be operating pruperily, are tho shaft encoders and collector drive mechanism.

DATA REQUIREMENTS: The angular position at either end of each of the four troughs when pointing in the furthermost north and furthermost south positions. While the troughs are traversing the arc from north to south the shaft encoder data shall be recorded at approximately 15-degree intervals. When the collectors are within 15 degrees of vertical, shaft encoder data shall be taken for each 5 degrees of travel until the collectors have traversed through the vertical position to 15 degrees south of vertical.

\subsubsection{Long-Term Distortion of Structure}

TEST OBJECTIVE: To determine how nearly each reflector approximates a perfect parabola and how the structure distorts from the parabolic shape with time.

The test description and conditions and data requirements are precisely the same as for Laser Evaluation of Reflector/Structure (see Section 2.1.9).

\subsection{Control}

This section of the Collector Subsystem Tests deals with control of this subsystem.

\subsubsection{Mixing Control}

\subsubsection{Morning Startup}

TEST OBJECTIVE: To determine the time required for the collector field to collect enough energy to begin placing $590^{\circ} \mathrm{F}$ fluid into the storage tank. 
TEST DESCRIPTION: This test consists of having the collectors in focus as soon as the sun comes up in the morning. Fluid is then circulated through the collectors and the blending tank until the desired operating temperature of $590^{\circ} \mathrm{F}$ is reached. The time required to accomplish this will be monitored and recorded.

TEST CONDITIONS: This test requires proper operation of the solar tracking system, the collector field transfer pump, and data acquisition system. Optimum conditions also require a clear sky. This test should be conducted several times during the year to determine the effects that the various weather and solar conditions excrt on the system.

DATA REQUIREMENTS: The collector field printouts from the minicomputer provide adequate data for this test. A continual plot of the solar time versus temperature at control valve V5 will give the rate of temperature increase. Data is needed on solar insolation versus solar exposure time to determine variation and effect on heat rate.

\subsubsection{Noon Startup}

TEST OBJECTIVE: To determine the time required for the collectors to collect enough energy to begin storing fluid at $590^{\circ} \mathrm{F}$ into the high-temperature storage tank. This condition would simulate conditions of a cloudy sky that clears up around noon. Knowledge of the time required for startup could be used to determine if it would be economical to attempt solar energy collection.

TEST DESCRIPTION: The test consists of having the system in the stored position until about noon. Then the system is started and the collectors turned into fucus. The temperature of the collectors, blending tank, and associated piping and pumps are at ambient temperature that is typical of night shutdown. At approximately noon the collectors will be turned into focus and the time required for the system to preheat until $310^{\circ} \mathrm{C}$ fluid is available at storage control valve V5 will bc recirled. This test will be repeated at various times throughout the year.

TEST CONDITIONS: The collectors will be in stowed position until about noon and all temperatures ambient, as they would be by remaining off overnight. The collectors will have been cleaned recently and a relatively clear day will be required. This test, as with all startup time tests, will be repeated at intervals throughout the year. The effect of various solar and weather conditions can be determined.

DATA REQUIREMENTS: The collector field minicomputer printouts provide the majority of necessary data. Times of beginning the test, as well as the time required for valve V5 to open, will be recorded by the operator.

The data required from this test will be primarily andlog data from the strip chart recorder. The strip chart recorder will need to be adapted to print out data from flow meters FM-1 and . 
FM-2, as well as thermocouples on the east end of the southwest collectors and the west end of the southeast collectors. The computer will be used to evaluate the temperature rise of the collectors in this mode, thereby determining if enough energy can be collected to make this a viable mode of operation. A minimum temperature rise of $110^{\circ} \mathrm{F}$ in two banks of collectors is required. This may not be feasible because of the necessarily reduced flow rates.

\subsubsection{Buffer Control}

\subsubsection{Morning Startup}

TEST OBJECTIVE: To determine the time required for the collectors to provide enough energy to begin placing $590^{\circ} \mathrm{F}\left(310^{\circ} \mathrm{C}\right)$ fluid into the storage tank when the blending tank is in the buffer mode of operation.

TEST DESCRIPTION: For this test the collectors are placed in focus by sunrise to begin collecting energy. The blending tank is empty of fluid so that input to the collectors comes from the bottom of the storage tank. The fluid from the collector field is placed into the blending tank until sufficient temperature $\left(310^{\circ} \mathrm{C}\right)$ has been reached to open control valve V5 and pump hot fliud into storage.

The fluid, thus stored in the blending tank, is fed back into the system at a controlled rate to avoid any large temperature differential between fluid coming from the bottom of the storage tank and fluid in the blending tank.

There also is a high level switch in the blending tank that will force fluid from the blending tank into the collector loop if the tank gets too full. Thus, if the time for startup in the buffer mode becomes excessive, there could be slugs of fluid from the blending tank alternating or mixing with fluid from the storage tank. This temperature varıation would have an unwanted effect on the input temperature to the collectors. The output temperature from the collectors could also be affected and result in disturbance of the storage tank thermocline.

TEST CONDITIONS: This requires proper operation of the sular tracking system, the collector field transfer purnp, and data-acquisition systcm. Tlime of opening valve V5 will be recorded by operator observance. Optimum conditions require a clear sky, clean reflectors, and clean receiver tubes. The test should be conducted at intervals throughout the year to determine weather and solar variation effects.

\subsubsection{Noon Startup}

TEST OBJECTIVE: To determine the time required to begin placing hot fluid $\left(310^{\circ} \mathrm{C}\right)$ into storage if either mechanical or meteorological conditions require startup other than in the early morning. It can be used to assist in determining if sufficient energy can be collected to warrant a late startup time. 
TEST DESCRIPTION: There are.many times when weather conditions preclude turning the collector system into focus early in the morning. The conditions often clear up in the late morning or early afternoon. It is then possible to place the collectors in focus and collect enough energy to store fluid in the high-temperature storage tank. The time required to heat up the system to adequate temperature for storage $\left(310^{\circ} \mathrm{C}\right)$ will help determine if adequate energy can be stored to warrant turning the collectors into focus and starting the collector and storage system.

The blending tank will be used in the buffer mode, e.g., it will cycle back the fluid from the collectors until a sufficiently high temperature for storage is reached. Fluid is fed into the system from the blending tank so that the input temperature to the collectors is stable. It is possible for the blending tank to completely fill with fluid. A high level switch then forces fluid from the blending tank through the collectors. If this happens, there may be either alternating slugs of hot and cold fluid through the collectors, or a collector input temperature other than that desired. Thus it is necessary to ascertain how long it takes to heat the system.

TEST CONDITIONS: The collectors will be in stowed position until about noon and all temperatures ambient, as they would be by remaining off overnight. The collectors will have been cleaned recently and a relatively clear day will be required. This test, as with all startup timc tests, will be repeated at intervals throughout the year. The effect of various solar and weather conditions can be determined.

DATA REQUIREMENTS: The collector field minicomputer printouts provide the majority of necessary data. Times of beginning the test, as well as the time required for valve V5 to open, will be recorded by the operator.

The data required from this test will be primarily analog data from the strip chart recorder. The strip chart recorder will need to be adapted to print out data from flow meters FM-1 and FM-2, as well as thermocouples on the east end of the southwest collectors and the west end of the southeast collectors. The computer will bc uged tu evaluate the temperature rise of the collectors in this mode, thereby determining if enough energy can be collected to make this a viable mode of operation. A minimum temperature rise of $110^{\circ} \mathrm{F}$ in two banks of collectors is required. This may not be feasible because of the necessarily reduced flow rates.

\subsubsection{Effects of Two Parrallel Rows of Collectors on Control}

TEST OBJECTIVES: To compare the efficiency and pumping losses of collectors set up in parallel with collectors set up in series. A secondary objective is to determine the flow rate and efficiency of valve V7 during this parallel setup.

TEST DESCRIPTION: Mode of operation: Flow is divided by control valve V7 and is routed in parallel through the northeaot and southeast collector banks, and is then mixed with the output of the northwest and southwest collector banks, which are also set up in parallel. 
There are two controls over flow. Via a thermocouple, the output temperature of the collectur banks controls the pump speed. The collector output from the southeast quad (west thermocouple in the southeast collector), and the southwest quad (east thermocouple in the southwest collector) combine to control valve V7. The position of this valve determines the ratio of flow in each direction.

TEST CONDITIONS: The conditions of this test require determining if the system will stabilize into an equilibrium condition when these two control mechanisms are operating, or if they will create an unstable condition that will not dampen out. There is a possibility that the time of detection and reaction of the two controls could cause an instability.

This system will be initially set up to operate in parallel to determine if it will arrive at an equilibrium state, which may be a worst-case condition because of the cold fluid at startup and the relatively rapid heating rate. If the system does reach a steady state, then the collector banks will be turned out of focus one at a time and then back in focus to see if it will again reach a steady state.

DATA REQUIREMENTS: The analog data from strip chart recorder. The strip chart recorder will need to be adapted to print out data from flow meters FM-1 and FM-2, as well as from the thermocouples on the east end of the southwest collectors and the west end of the southwest collectors. The computer will be used to evaluate the temperature rise of the collectors in this mode. It can therefore be determined if enough energy can be collected tu makt the parallcl setup a viable mode of operation. A temperature rise of $110^{\circ} \mathrm{F}$ in both banks of collectors is the minimum requirement to make the parallel setup viable. This degree of temperature rise may not be possible because of the reduced flow rates that are attendent to the parallel setup.

\subsection{Miscellaneou's}

This section of the Collector Subsystem Tests deals with miscellaneous tests.

\subsubsection{Field Pipe Heat Loss}

TEST OBJECTIVE: To determine the steddy-state instantancous heat loss of the rollector field pipe system. This is to be accomplished by measuring the difference between the heat collected in the collector field and the heat injected into the tank.

TFST DESCRIPTION: In a dynamic situation, the flow of heat in or out of any portion of the system is defined by the equation:

$$
\frac{\mathrm{d} Q}{\mathrm{dt}}=\Delta \mathrm{T} \times \mathrm{C} \times \text { flow } \times \rho
$$


Where $C$ is specific heat; $\rho$ is density; and $\Delta \mathrm{T}$ is $\mathrm{T}_{\text {in }}-\mathrm{T}_{\text {out }}$. The total heat input (or loss) is then the integral over time of this equation. If the test is controlled such that the difference in temperature is constant with respect to time, and the average temperature (and hence the specific heat as a function of temperature) is constant, then the total heat in or out of the sytem is simply $\Delta \mathrm{T}$ times specific heat times total mass flow through the system during the time interval.

In the solar total energy heat facility, each of the four collector panels has a well-matched pair of thermocouples, one at the input and one at the output. Thus, the temperature gained by a fluid flowing through each collector is fairly accurately known. Therefore, the total heat input is also known. By summing over the four collectors, the total energy gathered for a given period of time can be determined. This is defined as the total heat collected.

In the high-temperature storage tank there are thermocouples to measure the temperature at the hot-fluid input diffuser at the top of the tank, the oil temperature as a function of depth in the tank, and the temperature of the cold fluid withdrawal diffuser. In a steady-state dynamic flow situation, the heat into the tank would be the temperature of the input fluid minus the temperature of the output fluid times the average heat capacity times the mass flow.

This test would then consist of:

1. Bringing the entire collector field and its associated plumbing to a steady state (e.g., one in which all system piping and thermal mass elements have achieved an equilibrium, and the oil temperature in and out and the temperature difference are reasonably static with respect to time).

2. Establishing a thermocline at the top of the tank, or using the heater or cooler systems to maintain a constant output temperature.

3. Recording the temperature in and out of eaclı cullector so as to measure the total energy collected for a stated interval of time, and measuring the temperature in and out of the ștorage tank for the same interval of time to measure the total heat collected and the total heat placed in the storage tank. The difference in the two totals then is the amount of heat lost in the field piping.

TEST CONDITIONS:

1. The tank should be almost completely full of oil at the low temperature $\left(475^{\circ} \mathrm{F}\right)$

2. The focusing system must be properly operating

3. A clear, sunny day provailing

4. The system shall have been operated for a period of time adequate to establish steady-state conditions throughout the rillector, plumbing and sturiage tank. 
The following conditions are desireable but are not necessary for running this test:

1. A low outside ambient temperature which would maximize conductive heat losses

2. A constant $\Delta T$ in each of the four collectors

3. A time-stable thermocline is desirable so that the temperature output at the cold end of the tank is constant throughout the duration of this test, however, the heater or cooler systems can be used to achieve this effect.

This, in conjunction with a constant $\Delta T$, will insure a constant average temperature and hence a constant heat capacity with respect to time. Prior to the beginning of this test a sample of fluid should be withdrawn so that heat capacity can be accurately determined at the time of the test.

The instrumentation system calibration data should be made available so that accurate interpretation of the data is possible. In lieu of this, a systematic statistical analysis of the errors involved in acquiring and processing the data should be performed.

\section{DATA REQUIREMENTS:}

1. The output of the thermocouples at the input and output ends of each of the fuur collector panels

2. Temperature readings of all thermocouples and plumbing between the collector field and the storage tank

3. Temperature readings of all of the thermocouples with the tank

4. Flow of heating oil through the heat transfer pump

5. Ambient temperature as a function of time throughout this test.

\subsubsection{Overnight Field Heat Loss}

TEST OBJECTIVE: To determine the total heat los in the collector field and associated piping when the system is left defocused and undisturbed for a long period of time.

TEST DESCRIPTION: Just prior to the end of a business day, the collector reflectors will be defocused, and the collector field and associated piping will be filled with hot oil (approximately $\left.600^{\circ} \mathrm{F}\right)$. The temperature outputs from all thermocouples in the field and assoclated piping shall be recorded. Then the system shall be left undisturbed from the end of the business day until the beginning of the following day. 
On the morning of the following business day, prior to starting the pumps or focusing the collectors, the temperature outputs of all the thermocouples in the reflector field and associated piping shall again be recorded.

TEST CONDITIONS: Prior to startup of the test sufficient fluid to fill the entire collector field and associated piping shall be heated to $600^{\circ} \mathrm{F}$ in the blender tank. It would be desirable to run this test on a cool winter evening, however, this is not necessary. The test can be run under any environmental conditions, providing those conditions are known and recorded.

DATA REQUIREMENTS: The temperature output of all of the thermocouples in the collector field and associated piping at the beginning and end of a test. In addition, the temperature profile from the beginning of the test to the end shall be recorded on a thermograph. The total mass of fluid in the piping shall be derived analytically. The total thermal mass of the associated piping is required as an input to this test and this data shall be determined as a result of the test described in Section 4.3 .2 .

\subsubsection{Daily Pump Power Versus Energy Collected}

TEST OBJECTIVE: To determine the fluid-transfer-pump-power requirements as a percentage of the total collected energy during a complete day's operation.

TEST DESCRIPTION: This test consists of a complete working day's operation with the solar collectors in focus, the heat being collected, pumped to the storage tank, and then dissipated through the heat exchanger or the fluid cooler. Throughout the course of this day's operation the fluid-transfer-pump power consumption will be monitored continuously using a kilowatt-hour power meter. The total energy collected shall be determined by measuring the temperature in, the temperature out, and the fluid flow through each of the four collector panels.

TEST CONDITION3: It is required that this test be performed on a clear, sunny day (less than 10 percent cloud cover), and that the collector tracker system be operating properly. This test requires that the fluid-transfer-pump and all of the data-acquisition thermocouples be operating properly throughout the course of the day. The energy collected must be dissipated by use of the ORC turbine or the oil cooler.

DATA REQUIREMENTS: To determine the total pump energy requirement for the day, a continuous rccording of lie purnp Input power is required. An alternative means of monitoring the pump energy requirements would be the use of a kilowatt-hour meter similar to that used by commercial electric power companies. To record the total energy collected, the temperature in and out of each of the four collector panels and the flow through the collector field is required. It would be desirable to have an automated computer program which would periodically sample all the paraineters and automatically compute cumulative total energy collected and cumulative total power supplied to the pump. 


\section{STORAGE SUBSYSTEM}

\subsection{Thermocline Stability}

This section of the Storage Subsystem Tests deals with the thermocline stability of this subsystem.

\section{1 .1 Stat1c Stablllly}

TEST OBJECTIVE: To determine the ability of the high-temperature storage tank to maintain a thermocline for a reasonable period of time. This ability to maintain a sharp thermocline depends on heat conduction across the thermocline, heat lust lo the surrounding medium, and currents created in the liquid which produce flow across the thermocline.

TEST DESCRIPTION: There are two methods of establishing a thermocline in the hightemperature storage tank. First, the tank can be full of fluid at the cold temperature $\left(243^{\circ} \mathrm{C}\right)$ and the thermocline established by pumping high-temperature fluid $\left(310^{\circ} \mathrm{C}\right)$ through the top diffuser as the cold fluid is withdrawn from the tank. This establishes the thermocline at the top of the tank and moves it down the tank. Second, the tank can be full ot hot fluld $\left(310^{n} \mathrm{C}\right)$, whicli is pumpcd out, cooled to the low temperature $\left(243^{\circ} \mathrm{C}\right)$, and replaced in the bottom of the tank. This establishes the thermocline at the bottom of the tank and moves it up the tank. Either of the procedures can he used during operational conditions.

TEST CONDITIONS: The first test will be to heat the contents of the storage system to just above $243^{\circ} \mathrm{C}$. 'The system shall then stand so that thermal equilibrium can be reached. Then the fossil-fuel heater is used to heat the fluid to $310^{\circ} \mathrm{C}$ and establish the thermocline at the center of the high-temperature storage tank. The system will be closed down and the temperature profile recorded at intervals. The tank will be left undisturbed for a long period of time to determine long term stability.

The second test will be to heat the storage system contents to $310^{\circ} \mathrm{C}$ and allow it to reach thermal equilibrium.

DATA REQUIREMENTS: The high-temperature storage-tank thermocouple probe reading6, provided by the minicomputer printout, provide the necessary data. Periodic printouts of these data can be used then to compare the newly established thermocline with that at any selected interval throughout the test; printouts every half hour during the initial stages will be obtained, and then after several hours (i.e., overnight). This will establish both the short-term and long-term requirements. 


\subsubsection{Dynamic Stability}

TEST OBJECTIVE: To determine how sharp a thermocline of the high temperature storage system can be established and how well it can be maintained under dynamic conditions.

TEST DESCRIPTION: The energy collection rate by the collectors varies directly with time of day and solar intensity. Thus, the flow rate varies with the energy collection rate. This changing flow rate may have an effect on the sharpness of the thermocline. This effect, if any, will be studied during this test.

The rate of energy usage from the storage system can also vary greatly, depending upon energy requirements. Thus, the flow rate of fluid that is removed from the storage system, cooled and pumped back in the bottom of the storage tank also may vary significantly. The effect on thermocline sharpness of this flow rate will be studied also.

TEST CONDITIONS: The storage system will be heated to $243^{\circ} \mathrm{C}$ and allowed to reach thermal equilibrium. Then a thermocline is established at the midpoint of the tank. The heater will be used to vary the flow rate of the hot $\left(310^{\circ} \mathrm{C}\right)$ fluid through the top diffuser into the tank. The heating rate, as well as the flow rate, can be varied. Periodic printouts of the tank temperature profile will be obtained to determine the change in thermocline.

When the storage system is full of $310^{\circ} \mathrm{C}$ fluid, the heater will be shut off and the turbine started. The electrical load of the turbine will be changed to vary the energy requirements and the flow rates. The periodic minicomputer printouts of storage-tank temperature profiles and flow rates will allow determination of the thermocline and changes in its sharpness, if any.

DATA REQULEMENTS: The minicomputer printouts at intervals of one to two minutes. This will provide the storage-tank temperature profiles, the flow rate through the boiler and pump, and the electrical load of the turbine. These data can be used then to evaluate performance of the thermocline under dynamic conditions.

\subsubsection{Long-Term Stability}

TEST OBJECTIVE: To determine the ability of the high-temperature storage tank to maintaln a thermocline for long perlods of timè.

TEST DESCRIPTION: This test will be conducted in the same manner as in Section 3.1.1 with the thermocline at about mid-tank. Often the tank will set over weekends and occasionally over extended weekends. This test can determine whether a thermocline will exist even after an extended period of time. Data will be recorded at frequent intervals during the early part of this test (on the last business day of the week) to determine a thermocline diffusion rate. The entire system will then remain passive over the weekend. On the following Monday morning data will again be taken at frequent intervals to establish a diffusion rate and a tank heat loss rate. 
TEST CONDITIONS: No special test conditions are required. The storage-tank temperature probe will provide all the data necessary through the minicomputer printout. The initially established thermocline should be as sharp as possible. The temperature above the thermocline should be nearly uniform at $310^{\circ} \mathrm{C}$, and below the thermocline it should be uniform at $243^{\circ} \mathrm{C}$. The fluid below the bottom diffuser presents a problem in that it cannot be heated uniformly with that above the diffuser, however, this will not affect the thermocline stability study if the thermocline is well above the diffuser (i.e., at mid-tank).

DATA REQUIREMENTS: The temperature probe readouts provided by the minicomputer. These will be plotted as temperature versus height in the storage tank for selected times.

\subsubsection{Sensitivity to Out-of-Tolerance Fluids}

TEST OBJECTIVE: To determine the effect of fluid temperatures that are either hotter or colder than tank-fluid-storage temperatures on thermocline stability. This should help to determine the temperature limits that can be used to store energy in the high-temperature storage subsystem.

TEST DESCRIPTION: The high-temperature storage tank will be heated to $243^{\circ} \mathrm{C}\left(470^{\circ} \mathrm{F}\right)$ and allowed to reach thermal equilibrium. Then the thermocline will be established at near midtank. The hot fluid will be provided by use of the fossil-fuel heater. The temperature of the hot fluid will be controlled at $310^{\circ} \mathrm{C}\left(590^{\circ} \mathrm{F}\right)$ as closely as possible. This procedure should provide as sharp a thermocline as can be established in this system.

The thermocline will be re-established--if the hot fluid has destroyed it--by pumping ronider fluid into the top of the tank. Tank temperature profiles will he rennrier aga in to retermine the effect of the colder fluid. Because of its higher density, the colder fluid should start to sink to the bottom of the tank. This sinking will continue until the colder fluid has absorbed enough heat from the flutd it is passing through to reach thermal equilibrium with its surrounding fluid. Sinking of the colder fluid may cause currents in the tank that could significantly degrade the thermocline. The temperature of the fluid that would measurably degrade the thermnriline is nnt knnxm It may be necessary to conduct this test with increasingly colder fluid to more thoroughly understand its effects.

TEST CONDITIONS: No special conditions are required for this test. Care should be taken to insure that a uniform temperature exists both below and above the thermocline interface. The out-of-tolerance fluid should be placed in the tank soon after the thermocline is established to avoid confusion with the natural diffusion of the interface.

DATA REQUIREMENTS: Tank temperat ure readings from the minicomputer, fossil-fuel heater output temperature, and flow-rate of the boiler pump. The thermocline profile and the temperature and quantity of fluid placed in the tank can be determined from these data. 


\subsubsection{Liquid Level Versus Temperature}

TEST OBJECTIVE: To obtain a means of determining the amount and level of liquid fluid in the storage tank using the external sight glass.

TEST DESCRIPTION: The density of fluid liquid varies considerably as a function of temperature. Because the fluid in the storage tank normally is kept at elevated temperatures $\left(450^{\circ}\right.$ to $600^{\circ} \mathrm{F}$ ), and the liquid in the sight glass is normally at the local ambient temperature, there can be significant differences in the liquid level of the two columns of fluid. If the average temperature of each column, and hence the average density, is accurately known, then the liquid level in the tank can be determined accurately from the liquid level in the sight glass. The temperature of the fluid in the storage tank is monitored at many locations in the tank by thermocouples mounted in the tank sides. The temperature sensed by these thermocouples is sampled and printed out by the system-control-computer printer. Simple arithmetical averaging of these temperatures will give the average fluid temperature, and therefore the average fluid density with adequate accuracy.

The sight glass is connected to the bottom of the storage tank by an integral metal threaded and welded pipe. This pipe goes through the insulating vacuum jacket near the bottom of the storage tank and runs vertically parallel to the storage tank for approximately two meters where it is connected to a transparent tube surrounded by metal. The top of the sight glass is connected to. the top of the storage tank by means of a tap into the nitrogen-pressurization-blanket tubing. The sight-glass tubing does not have thermocouples incorporated in it. Therefore, the temperature of the tube and of the fluid can vary in an unknown manner. Factors which influence these temperature variations include heat conduction through the metal pipe at the bottom connection to the stor-age tank, ambient air lemperature, and radiant heating from the sun.

This test will consist of measuring the temperature of the sight-glass tube as a function of height above the bottom connection to the storage tank. If the temperature variations 2 ro lnown, the average temperature, and hence the average density, can be determined. Given the average temperature and the measured helght of the sight-glass liquid level, the pressure at the bottom of the tube can be derived. This pressure will be equal to the pressure at the same elevation in the storage tank, and given the average temperature and density of the oil, the liquid level in the tank can be determined. As a backup to the temperature measurements which infer differential pressure, the differential pressure will be measured directly by installing accurate $( \pm 1 / 2$ inch) water pressure gauges at the nitrogen blanket and at the bottom of the storage tank.

These data will be analyzed in sufficient depth to determine the minimum number of thermocouples which must be installed on the sight-glass tubing to determine adequately the average temperature of the sight-glass fluid. The results of this test will be presented as a curve or family of curves which will give liquid level in the tank as a function of average temperatures and sightglass levels. 
TEST CONDITIONS: There are no environmental or operational conditions required for this test. However, it is recommended that the test be performed when the tank fluid is at or above the minimum operating temperature, i.e., $470^{\circ} \mathrm{F}$. This test should be performed at least twice, once without direct solar radiation on any portion of the sight tube plumbing and once with direct solar radiation on exposed portions of the sight tube.

DATA REQUIREMENTS: The temperature of the sight tube plumbing as a function of location on the tube, the storage thermocouple readings, and the differential pressure as measured at. the top and bottom of the storage tank.

\section{2 Thermal Losses and Mass Effects}

This section of the Storage Subsystem Tests deals with therinal losses and mafs effects of this oubrystem.

\subsubsection{Insulation Thermal Evaluation}

TEST OBJECTIVE: To evaluate the effectiveness of the high-temperature storage-tank vacuum jacket and thermal insulation in protecting against heat loss.

TEST MF.SRRIPTION: This test consists of several steps that are designed to provide a method of evaluating insulation effectiveness. The vacuum jacket of the storage tank consists of two concentric cylinders that are 13 feet high and about 7 feet in diameter with a vacuum thickness between them of twu fuclies. This vacuum has 75 layers of a vacuusp-fuil-insulation material in it to assist in reducing heat loss.

TEST CONDITIONS: The first step is to determine the capability of the vacuum pump to provide an adequate vacuum. The vacuum gauge is mounted on a pipe between the pump dnd lite latk (Figure 4). The vacuum reading on the gauge, after long-term pumping, should read 0.25 inches $\mathrm{Hg}$. To determine if this is a maximum reading, the hose to the pump should be blanked off and a vacuum gauge put in place to read the vacuum. This will delermine the grcatest vacuum the pump can provide. If 0.25 inches $\mathrm{Hg}$ is the maximum, determination of its adequacy will be madc.

The second step is to provide a second vacuum reading on the opposite side of the tank and at the top of the vacuum jacket. This reading will provide information on the ability of the pump to pull a vacuum past the vacuum foil and around the tank. This will also indicate leaks in the system if any exisl.

The effectiveness of the existing vacuum will be studied. This study will be a comparison of heat loss of the tank with and without a vacuum. The storage-tank fluid will be heated and the tank closed off. The tank will be left overnight and the heat loss measured. The storage-tank fluid will be heated again and left overnight with no vacuum on the jacket. Then the temperature losses, with and without the vacuum, can be compared. 


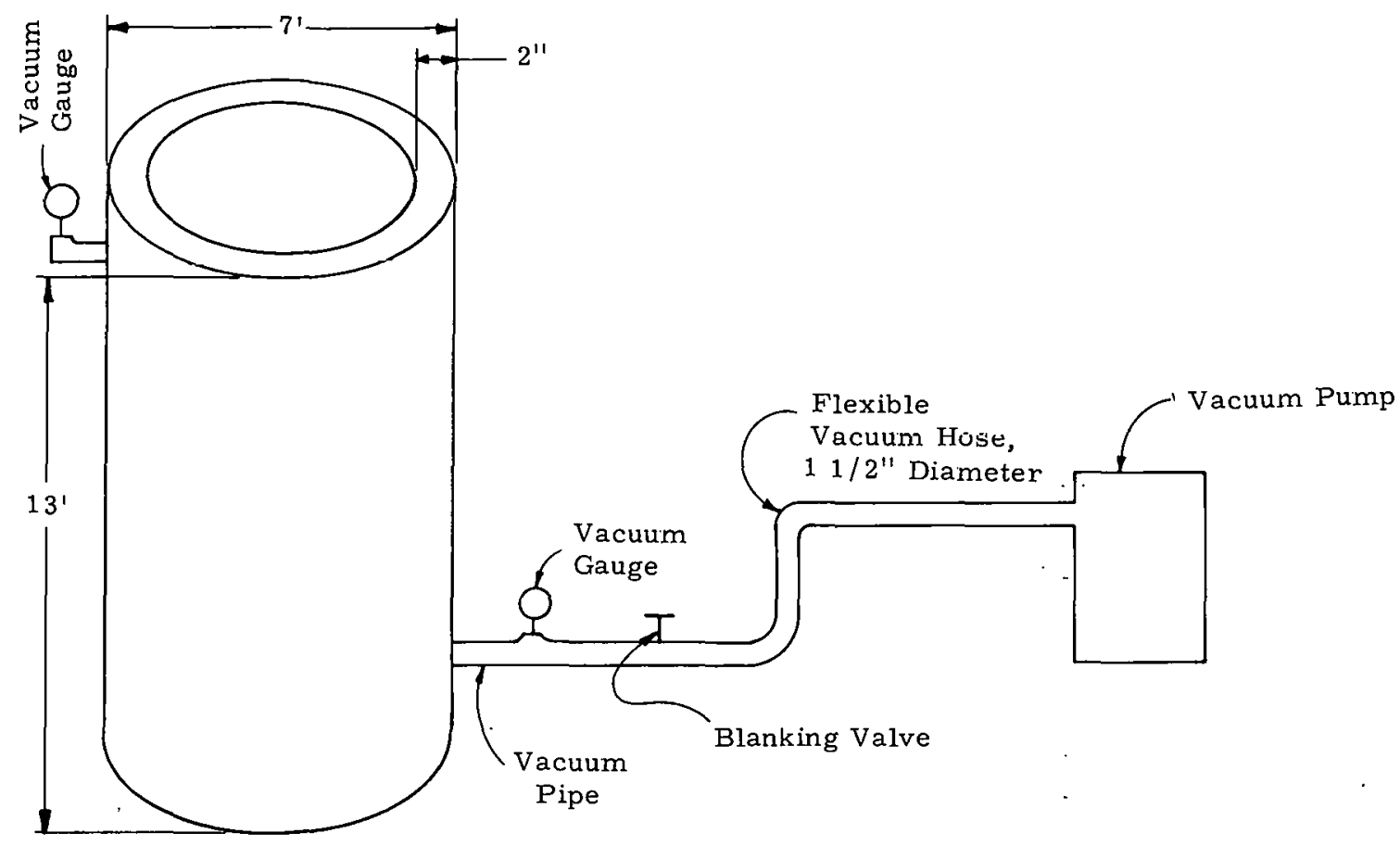

Figure 4. Schematic of Insulation Thermal Test Setup

DATA REQUIREMENTS: The tank temperature thermocouple readings. The temperature profile, after heating and after sitting overnight, can be compared from these data to determine temperature loss.

\subsection{Control}

This section of the Storage Subsystem Tests deals with control of this subsystem.

\subsubsection{Automatic Cooler Mode Operation}

TEST OBJECTIVE: To evaluate the fluid cooler operation in its automatic mode.

TEST DESCRIPTION: The fluid cooler is designed to dissipate excess heat which may be pumped into the high temperalure sturage tank. 'I'he cooling system has sensing thermocouples and controllers that will function when the storage tank is full of high temperature fluid. When this occurs, the cooling system will switch cooling valve V8 (Figure 5) to direct hot fluid to the cooler, turn on the fluid cooling pump, and adjust temperature control valve V9 to the preset position to return fluid to the tank. Normally, the controllers are set so that valve V8 opens at about $310^{\circ} \mathrm{C}\left(590^{\circ} \mathrm{F}\right)$, and valve V9 returns fluid to the bottom of the storage tank at $243^{\circ} \mathrm{C}\left(470^{\circ} \mathrm{F}\right)$. 


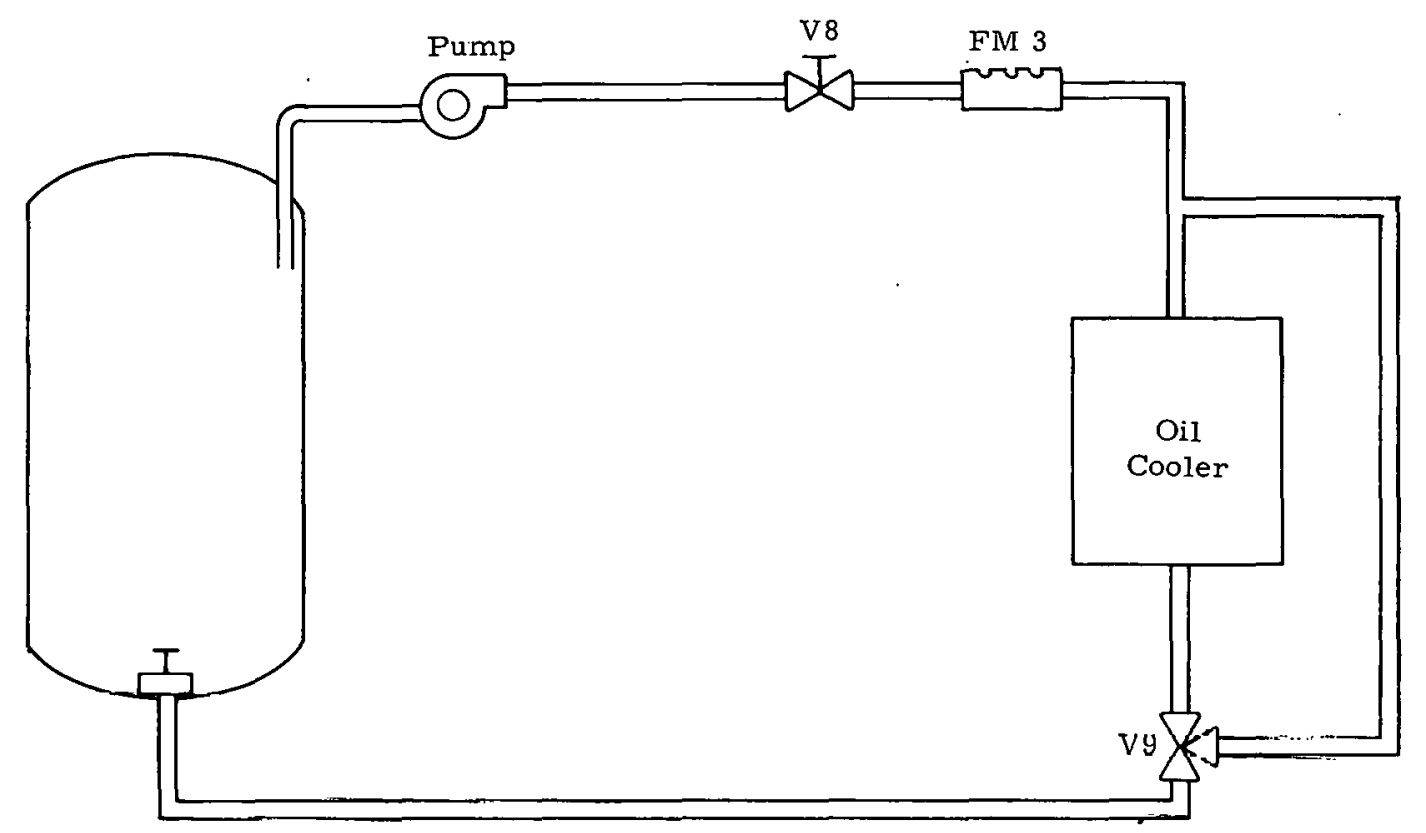

Figure 5. Schematic of Auto Cooler Mode Operation

TEST CONDITIONS: The temperature sensor for valve V8 is located near the bottom diffuser of the storage tank. Thus, when the tank is as full as possible with high temperature fluid, the valve opens, the pump starts, and the cooling system is started. The sensor should be located somewhere above the diffuser also so that when sufficient cool fluid is placed back in the tank, the V8 sensor detects it and stops the operation. The V8 sensor is currently 24 inches above the bottom diffuser. If the cooling system is operated through its range, a determination can be made as to whether the sensor is at an adequate level. Determination can be made also as to whether the cooling system is adequate in the automatic mode.

DATA REQUIREMENTS: Monitoring the oll cuoler system for times of operation, fluid flow rates, valve V9 operation, and the tank-terriperature profile thermocouple rendout; of the minicomputer.

\section{3:2 Automatic Heater On/Üf Operatlun}

TEST OBJECTIVE: To evaluate automatic heater operation.

TEST DESCRIPTION: The automatic heater on/off operation is designed to control the fussilfuel heater which serves as a.back-up heating system for the high temperature tank when there is insufficient solar energy to heat the collector field: The high temperature storage tank will provide some reserve for evening and morning use. However, in event of extended low solar insolation periods, the fossil-fuel heater will be required. Control of this heater is automatic. A thermocouple inside the storage tank sends a startup signal to the heater when a designated low temperature is reached: This thermocouple will be set so that sufficient energy remains in the storage 
tank to continue turbine operation while the heater system goes through its startup procedures. Once the heater system has started signal will be given to complete the changeover. An evaluation will be made of these signals as to how they and the controllers operate.

TEST CONDITIONS: A requirement also exists for the heater system to be automatically switched off, e.g., if the turbine is operating from the fossil-fuel heater system and sufficient solar energy becomes available to assume the load, the sensors will detect this condition and cause the system to automatically switch to operation from the collector/storage system. Then the heater would shut off automatically.

The procedure to test heater-on operation will be to operate the turbine system from the storage system. When the energy level is low enough so that only enough energy remains to provide time for heater startup (approximately 2 minutes), the heater will be started. When the heater flame has ignited, the system will be switched over to the heater operation mode. Cold fluid will be present in the heater system and may or may not shut down the turbine. In case of shutdown it may be necessary to purge the heater with warm fluid to avoid sending a cold slug of fluid through the boiler before heater ignition. The requirement for this purge, and a determination of when the heater cycle should begin, will be decided from the results of these tests.

The automatic off mode will be tested to determine system reliability. The storage tank will be heated using the collectors. When sufficient energy is available to operate the turbine in a stable condition with a full $(32 \mathrm{~kW})$ load, the switch-over to storage operation will be made. This switch-over should send only a small amount of cold fluid to the boiler and should not interrupt turbine operation. Thus, the time it takes to accomplish the switch-over to storage can he determined.

DATA REQUIREMENTS: The minicomputer printout of the storage-tank temperature, the ORC system operational data and the analog strip charts of turbine operation are the required data.

\section{4 Miscellaneous}

This section of the Storage Subsystem Tests deals with miscellaneous tests of this subsystem.

\subsubsection{Maximum Withdrawal Rate From Storage}

TEST OBJECTIVE: To determine, for various liquid levels above the top diffuser, the maximum rate at which oil can be withdrawn from the top of the tank without causing a vortex that will allow gaseous nitrogen to be withdrawn with the fluid. Because a vortex is more likely to form in cooler fluid (due to the lower height of fluid in the lark), this test will be performed only at the minimum operating temperatures $\left(470^{\circ} \mathrm{F}\right)$. 
TEST DESCRIPTION: The following steps are required to implement this test:

1. The liquid level must be adjusted in the storage tank such that, at a temperature of $470^{\circ} \mathrm{F}$, it will be 13 inches above the upper diffuser (see Section 3.1.5).

2. A uniform temperaturc of $470^{\circ} \mathrm{F}$ must be established both in the tank and in the field piping which will be involved in this test. To accomplish this it is recommended that initially the fluid be allowed to cool below $470^{\circ} \mathrm{F}$. The fluid should then be circulated from the storage tank through the heater and back until the required temperature of $470^{\circ} \mathrm{F}$ is reached. It may be necessary to adjust the heater so that the ull leing hoatod osmes int. at slightly above $470^{\circ} \mathrm{F}$ to offset heat loss in the system. After uniform, or almost uniform, temperatures are roaohed, the temperatures, which are monitored by thermocouples in the tank and in those sections of tubing being utilized for this test, will be recordod.

3. The fluid-heater-transfer pump output must be slowly increased until the flow meter at that pump begins to oscillate. Oscillation of the flow meter output indicates that a vortex has formed and that gaseous nitrogen is being sucked out of the tank along with the fluid.

4. The liquid level in the tank must then be decreased by 4 inches and step No. 3 repeated. The liquid level in the tank will cunlinue to bc dcoreased by increments of 4 until the level is less than one inch above the diffuser, or until an obvious relationship between vortex formatıon and llyuid level ia ootablished

TEST CONDITIONS: There are no environmental conditions required for successful operation of this test. However, proper operation of the thermocouples in the storage turık, the heaterfluid-transfer pump, the transfer-flow meter, and the fossil-fuel heater is required.

DATA REQUIREMENTS: Temperature outputs of all of the appropriate thermocouples, a continuous recording (i.e., strip charts) of the fluid-transfer pump/flow-mèter outpul, dus lhe. calculated liquid level in the storage tank. 


\section{HEATER BOILER AND ORC SUBSYSTEM}

\section{1 Performance}

This section of the Heater Boiler and ORC Subsystem deals with the performance of this subsystem.

\subsubsection{Baseline ORC Performance}

TEST OBJECTIVE: To measure the heat input requirements needed to produce the fullrated output of the turbine generator system under the three condenser conditions - winter, fall/ spring, and summer.

TEST DESCRIPTION: This test will be performed by operating the turbine generator with hnt fluid supplied cither from the collectors, or from the heater, or from a combination of both. The turbine will be operated at a maximum full rated load of $32 \mathrm{~kW}$. The condenser cooling-water input temperature will be varied to simulate winter, fall/spring, and summer cooling conditions.

TEST CONDITIONS: The following procedure will be implemented to achieve this test's objective:

1. The condenser cooling-water input/output temperature will be adjusted to $170 /$ $190^{\circ} \mathrm{F}$ (simulated summer cooling conditions).

2. The heater fluid will be supplied at a constant $590^{\circ} \mathrm{F}$ input temperature to the oller of the turbine system.

3. The turbine power will be supplied to the dummy load.

4. All operating parameters will be adjusted to achieve a full $32 \mathrm{~kW}$ electrical load from the turbine to the dummy load.

5. Heat extracted from the oil will be measured to maintain steady-state operation.

This cycle will be repeated with the condenser cooling-water input/output temperatures adjusted to $95^{\circ} / 105^{\circ} \mathrm{F}$ and $105^{\circ} / 155^{\circ} \mathrm{F}$ to simulate winter and fall/spring cooling conditions. respectively. 
DATA REQUIREMENTS: The following parameters will be monitored continually during this test.

1. Temperature of heating fluid to the boiler.

2. Flow rate of heating fluid to the boiler.

3. Boiler temperature and pressure.

4. Turbine electrical output

5. Toluene temperature at inlet and outlet of condenser.

6. Cooling-water temperature at inlet and outlet of condenser.

7. Cooling-water flow rate through condenser.

\subsubsection{Transient ORC Performance - Heater Boiler Mode}

TEST OBJECTIVES: (1) To determine the minimum high temperature in the storage turık al which it is feasible to continue operating. (2) To determine the switch-over temperature at which the fossil-fuel heater should be operated to supply energy for turbine operation. (3) To determine the effect of a transient supply of cold fluid. (4) To incorporate the effects of a transient supply of cold fluid into an operational theory, determining the minimum tank temperalure and flow rate at which the fossil-fuel heater must be operated. (5) To demonstrate automatic switch-over operation.

TEST DESCRIPTION: When the turbine is operated from energy stored in the high lemperature tank, (i.e., when there is inadequate solar energy being transferred fiom the collcctor field to opcrate the turhine), the temperature uf the hot oil in the storage tank is steadily lowcred. To maintain full turbine outpul, the heat supplind to the hailer is maintained constant by increasing the flow rate as the temperature decreases. (This does not apply to a tank with a stable thermocline, as this condition affords a constant temperature output.) As the temperature of the output fluid decreases and the flow rate increases, a polnt is appruached wherc it becomes mandatory to supply additional energy from the fossil-fuel heater to maintain turbine operation.

When the decision is made to turn on the heater and the proper valve closures and upenings are made to cycle oil through the heater, cold vil stored in thc heater piping and associated plumbing will be routed to the boller. Therelore, during thle lausistint perind, hoat is not sontinunusly supplied to the boiler.

To start this test the storage tank will be filled with hot oil at $590^{\circ} \mathrm{F}$. Heat should be supplied by the solar collectors and the heater. Associated piping should be maintaitued at or near ambient temperature. When the tank is filled with $590^{\circ} \mathrm{F}$ oil, the solar collectors will be defocused. The boiler and turbine will be turned on then with the full-rated electrical power output of the turbine routed to the load bank. To preclude establishment of a thermocline and to insure a steadily decreasing storage tank temperature, fluid for the boiler should be drawn from the bottom of the storage tank rather than from the top. The test shall continue with the turbine operating at prescribed temperatures and pressures. As the test proceeds, the hot fluid temperature will decrease 
and the flow rate shall increase to maintain boiler design conditions. The test shall proceed until the temperature and flow rate of the oil are insufficient to maintain boiler operation conditions. These data will provide insight as to when additional heat is required from the fossil-fuel heater.

A separate test is required to determine the impact of the cold oil stored in the heater plumbing, which will be introduced to the boiler when the heater is turned on. To perform this test it is necessary merely to: operate the boiler turbine generator system at designed conditions with hot fluid provided from the storage tank; maintain the heater and its associated plumbing in relative equilibrium with the surroundings; observe the impact on boiler operations when the oil supplied to the boiler is switched-over from storage tank output to heater output.

TEST CONDITIONS: This test should be run on sunny days so that the storage tank can be brought to $590^{\circ} \mathrm{F}$ while the fossil-fuel heater and its associated piping are maintained at ambient temperature. Successful completion of this test requires that the ORC system, the dummy load, and the solar collector system all be operating properly.

DATA REQUIREMENTS: Boiler temperature and pressure, generator voltage current and frequency, oil temperature in and out of the storage tank, and oil temperature into and out of the boiler. All of the above data are required continuously throughout the test and should be taken with the strip chart recorders rather than sampled by the computer.

\subsubsection{Transient ORC Performance - Storage Boiler Mode}

TEST OBJECTIVE: To determine the impact of cold fluid influx into the ORC boiler (this occurs when boiler fluid input is switched from fossil-fuel heater to storage tank), and to demon= strate automatic switch-over operation.

TEST DESCRIPTION: When the ORC. hniler is operatcd from the fussll-fuel heater, and excess energy is available either from the heater or from the collector field, hot fluid will he placed in the storage tank. As the storage-tank temperature increases, the decision to shut off the fossil-fuel heater and operate the ORC turbine either from storage or from the solar collector field will be made. During the switch-over, cold oil accumulated in the piping between the storage tank/collector field and the boiler will be introduced to the boiler. This test will determine the impact that cold oil has on boiler operation. This test shall consist of monitoring boiler and generator operation while the boiler input is switched from heatcr to storage.

\section{TEST CONDITIONS:}

1. The ORC will operate with energy supplied by the heater.

2.' The storage tank will contain sufficient oil at $600^{\circ} \mathrm{F}$ to operate the turbine..

3. The plumbing between the storage tank and the turbine will have reached equilibrium with local ambient temperature. 
DATA REQUIREMENTS: Boiler temperature and pressure, oil temperatures at input and output of the boiler, and generator voltage, current, and frequency.

\subsubsection{Maximum ORC Output}

TEST OBJECTIVE: To determine the maximum electrical output the ORC subsystem can develop. This, and the associated flow rates and temperatures, will provide an upper limit on load requirements for the system.

TEST DESCRIPTION: The designed maximum electrical load of the ORC system is $32 \mathrm{~kW}$. To determine how well the system will carry thiu vontinunus lnad, and what parameters are required to maintain maximum operational load, it is necessary to determine the maximum load the system will handle. This test also will provide conditions that the associated subsystems must satisfy to allow development of the operational load. For example, the boller pump mußt bo able to supply a certain minimum flow to the boiler, or there will not be sufficient energy supplied to the turbine to carry its load. Knowledge of the maximum output from the ORC system is required in order to establish these minimum performance characteristics.

TEST CONDITIONS: The ORC system shall be set up to operate from the fossil-fuel heater. Conditions require that the input temperature of the fluid to the boiler be $300^{\circ} \mathrm{C}$ and the output be $243^{\circ} \mathrm{C}$. This will duplicate operating conditions. The initial load of $32 \mathrm{~kW}$ will be ajplied and, after stable conditions have been reached, incremental incredses will be applied until it heromes apparent that the maximum load has been applied, or that the maximum measuring capability of tho system has been reached.

DATA REQUIREMENTS: The minicomputer printout to provide temperature and flow conditions. The required steady-state conditions will be determined by a combination of the corriputer printout, the analog strip chart data, and the obscrvations of the experimenters.

\subsubsection{Out-of-Tolerance Temperature Effects}

TEST OBJECTIVE: To evaluate boiler turbine efficiency when operating at temperatures and pressures other than the designed lemperaturc and pressure. To accomplish this objective, the toluene flow rate and the fluid temperature and flow rate will be adjusted to vary the boiler operating temperature from $540^{\circ} \mathrm{F}$ to $600^{\circ} \mathrm{F}$, while maintaining the designed pressure of 230 psia, and to vary the operating pressure from 200 to 260 psia, while maintaining a temperature of $575^{\circ} \mathrm{F}$.

TEST DESCRIPTION: This test will begin with the ORC generator system operating under designed conditions. Energy will be supplied to the boiler by means of hot oil heated in the fossilfuel heater; the condenser will be operated in the winter condition. With the ORC generator operating at maximum output, and the temperature and pressure at designed conditions, the toluene and fluid flow rates will be varied to produce these out-of-tolerance conditions. 
During the first test series, pressure will be maintained at 230 psia while the temperature is reduced to $540^{\circ} \mathrm{F}$. The temperature will be gradually increased then in $10^{\circ}$ increments from 540 to $600^{\circ} \mathrm{F}$. The second test condition will be such that the temperature is maintained constant at $575^{\circ} \mathrm{F}$, while the pressure is reduced to $200 \mathrm{psia}$, and then stepped in increments of 10 psia to 260.

TEST CONDITIONS: There are no environmental conditions required for this test. It is required that sufficient hot fluid be supplied either from storage, the solar collectors, or the fossil-fuel heater to maintain the ORC at maximum output. The condenser outlet water temperature shall be controlled to simulate winter operation conditions.

DATA REQUIREMENTS: During this test the fluid temperature pressure and flow rate, toluene temperature pressure and flow rate, and the generator output shall be recorded.

\section{2 Control}

This section of the Heater Boiler and ORC Subsystem Tests deals with control of this subsystem.

\subsubsection{Heater Control Evaluation}

TEST OBJECTIVE: To verify the proper operation of safety controls for the heater ORC turbine system.

TEST DESCRIPTION: There are seventeen safety controls designed for protection of equipment and personnel. Sume of these controls are concerned with the fossil-fuel heater system, some are concerned with the ORC turbine system, and some are concerned with both. Figure 6 identifies the controls and the system(s) with which they are concerned, Some nf these controla are checked every time the system is operated, others are tested frequently, and the remaining ones will be cxamined during this test. These controls include stack overtemperature, lube overtemperature, sniffer, condenser overpressure, lube underpressure, unit overtemperature, and $\mathrm{CO}_{2}$ discharge.

- The stack overtemperature check will be conducted by removing the overtemperature sensor and heating it with a heat gun until the overtemperature condition signal is detected from tho ocnoor. 'The $\mathrm{CO}_{2}$ discharge will be disconnected and a dummy load substituted to provide detection of the signal that would normally discharge the $\mathrm{CO}_{2}$. The base fire station will be alerted to prevent response to the fire alarm signal.

The lube overtemperature system will be tested by removing the sensor, heating it with a heat gun, and checking that the proper signal is transmitted to the turbine control system and that the turbine is shut down automatically. The turbine will be runnisg at the beginning of this test. 


\begin{tabular}{|c|c|c|c|c|}
\hline No. & Safety Control & $\begin{array}{c}\text { System } \\
\text { Fossil- } \\
\text { Fuel } \\
\text { Heater }\end{array}$ & $\begin{array}{c}\text { ntrolled } \\
\text { ORC } \\
\text { Turbine } \\
\end{array}$ & Remarks \\
\hline 1 . & Heater overtemperature & $\mathrm{x}$ & - & OK. \\
\hline 2 & Stack overtemperature & $\mathrm{x}$ & $\mathrm{x}$ & Test (simulate) \\
\hline 3 & Lube overtemperature & - & $\mathrm{x}$ & Test (simulate) \\
\hline 4 & Sniffer & $\mathrm{x}$ & $\mathrm{x}$ & Test (actual) \\
\hline 5 & Airflow safety & $\mathrm{x}$ & - & OK \\
\hline 6 & Heater overpressure & - & $\mathrm{x}$ & OK \\
\hline 7 & Condenser overpressure & $\mathrm{x}$ & $\mathbf{x}$ & Test (simulate sensor) \\
\hline 8 & Lube underpressure & - & $x$ & Test (simulate sensor) \\
\hline 9 & $\begin{array}{c}\text { Fuel overpressure/ } \\
\text { underpressure }\end{array}$ & $\mathrm{x}$ & - & OK \\
\hline 10 & Flame failure & $\mathrm{x}$ & - & OK \\
\hline 11 & Overvoltage & - & $\mathrm{x}$ & OK \\
\hline 12 & Undervoltage & - & $x$ & OK \\
\hline 13 & Overspeed & - & $\mathrm{x}$ & OK \\
\hline 14 & Undcropced & - & $\mathrm{x}$ & OK \\
\hline 15 & Hotwell liquid, low & - & $\mathrm{x}$ & OK \\
\hline 16 & Unit overtemperature & $\mathrm{x}$ & $\mathrm{x}$ & Test (simulate sensor) \\
\hline 17 & $\mathrm{CO}_{2}$ discharge & $\mathrm{X}$ & $x$ & OK \\
\hline
\end{tabular}

Figure 6. Heater/ORC Turbine Safety Controls

The "sniffer" safety control is a toluene vapor detectur. If potentially hazardous toluene vapor is building up, one of three sniffers in the turbine room will detect this concentration and send signals that will shut down the turbine and heater systems, alert building occupants, and alert the base fire station. The system will be checked by placing a toluene saturated rag at the npening of the sniffer. The percentage of concentration required to operate the safety controls will be monitored with the toluene concentration gauge on the turbine control rack.

The condenser ovcrpressure safety system will be checked by disconnecting the sensor and introducing the proper signal into the system's electronics. This signal is designed to shut down the turbine and the fossil-fuel heater automatically. To insure that the system is operating properly, the turbine should be operating from the fossil-fuel heater when the condenser overpressure safety system is checked out.

The final safety system that needs to be checked is the unit overtemperature. This system, if activated, will discharge carbon dioxide bottles to combat a fire condition. To simulate the conditions, the sensor will be disconnected and a simulated signal introduced. The $\mathrm{CO}_{2}$ bottles will also be disconnected and replaced with a detector. While the turbine is running off the fossilfuel heater, the unit overtemperature signal will be introduced. The $\mathrm{CO}_{2}$ fire signal will be monitored and shutdown of the turbine and heater checked. 
These checks will complete analysis of the heater/ORC controls. Those that have been checked are identified with an $\mathrm{OK}$ in the Remarks column of Figure 6.

\subsubsection{ORC Control Evaluation}

TEST OBJECTIVE: To evaluate the capability of the ORC system controls in eliminating excessive temperatures, and pressure overshoots and undershoots when large changes in the electrical load occur. The amount of overshoot or undershoot will be measured and, if oscillations occur, measurement will be made of the time required for the controls to damp them out and resume steady-state operation.

TEST DESCRIPTION: When the turbine is started, it will operate with zero electrical load. Then, when operating conditions allow, an electrical load will be applied. The size of the electrical load can be varied but it is likely that the worst-case condition will occur when a maximum load is applied instantly. This will require a rapid increase in the flow of fluid through the boiler, and of toluene through the turbine. Time lapse between the control system's reception of signals to increase output, and the reaction of the pumping system will lead to an expected overshoot in the energy supplied. Then a time lapse in the attempt to counteract the overshoot will occur, resulting in an undershoot. The time-constant of the system response should damp these oscillations and force the system into a steady-state condition. Electrical loads exist that can be applied to the ORC system which the control system cannot handle. If this load is above the $32 \mathrm{~kW}$ maximum load designed in the system, it will not present a problem since such a load would be out of the system's operating range. The purpose of this test is to determine that the system will handle the worst-case conditions between no load and the $32 \mathrm{~kW}$ maximum load, and that the oscillations induced by the load change will be controlled and damped out so that steady-state conditions are achieved.

TEST CONDITIONS: The ORC system will operate from the fossil-fuel heater. It will operate at steady-state conditinns with a scro eleclrical load. The turbine temperatures and pressures will be recorded. The full load $(0+32 \mathrm{~kW})$ will be applied and conditions of the ORC system monitored and recorded. The peaks and valleys of each oscillation will be recorded as well as the time for the system to reach steady-state operating conditions. After steady-state conditions have heen reached, the load will be taken off $(32 \mathrm{~kW} \rightarrow 0)$ and the oscillations extremes and times taken again.

The above procedure will be repeated for loads of $0 \rightarrow 16 \mathrm{~kW}, 16 \mathrm{~kW} \rightarrow 0,16 \mathrm{~kW} \rightarrow 32 \mathrm{~kW}$, and $32 \mathrm{~kW} \rightarrow$ $16 \mathrm{~kW}$.

DATA REQUIREMENTS: The minicomputer printouts, the ORC strip chart records, and data from the digital displays on the turbine control rack. The digital displays will be the primary data source due to their continuous readout, and will be recorded at regular intervals by the operator. The $\mathrm{kW}$ electrical load applled can be obtained from the minicomputer. Other data recorded 
will be the turbine inlet temperature and pressure, the outlet temperature and pressure, the frequency of oscillations of each, and the time to achieve steady-state operation. The glycol-system temperature condition will be recorded also.

\subsubsection{Automatic Switching}

TEST OBJECTIVE: To provide information to the engineer that will help in the determination of proper setting of controls for automatic switch-over of turbine operation from storage mode to fossil-fuel heater mode, and from heater mode to storage mode.

TEST DESCRIPTION: The procedure for this test is the same as that in jectiong 4.1.1 und

4.1.2. The data obtained in these tests can be used here.

This test takes a minimum of three days because the system must cool to overnight temperatures before a new data point can be obtained. On the first day, the high temperature sturage tank is heated to $310^{\circ} \mathrm{C}$. Then the system is allowed to stand overnight. The turbine is started on the morning of the second day and set to operate with a continuous electrical load of $32 \mathrm{~kW}$. The turbine will operate from the high-temperature storage tank until the engineer and test directur. determine that the stored energy has been nearly exhausted. The fossil-fuel heater will be ignited then and the turbine operation switched-over to heater operation. The heater has an automatic purge cycle that takes about one and a half minutes to complete before ignition of the heatcr can take place. The switch-over time must allow for sufficient energy in storage to continue operarion for this heater startup time.

On the afternoon of the second day the high temperature storage tank will be heated again to $310^{\circ} \mathrm{C}$ and left overnight. The morning of the third day the turbine will be operated using the fossilfuel heater with an electrical load of $32 \mathrm{~kW}$. After steady-state operation has been reached the turbine operation will be switched to the storage system.

Proper selection of both switch-over points will assist in obtaining maximum efficiency in utilization of the system. These points are somewhat arbitrary, and a manually set controller will be utilized to select the desired temperatures. It is, howcver, uesul to determine the mini-

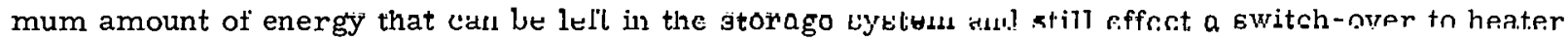
operation. Then the responsible engineer can select that temperature, or a slightly higher one, and be assured that the turbine will not shut-down due to lack of stored energy during heater startup time.

TEST CONDITIONS: This teșt requires a sufficient amount of energy in the storage tank to drive the turbine for switch-over from storage to heater operation. Proper operation of the fossilfuel heater is also required, as well as a $32 \mathrm{~kW}$ load on the turbine. 
DATA REQUIREMENTS: The minicomputer printout data is needed to obtain storage tank temperature profiles, as well as temperature and pressures of the boiler and turbine. The turbine and heater strip charts will provide analog data to determine heater startup time and flow rates. This data will be sufficient to accomplish the objectives of this test.

\section{3 Miscellaneous}

This section of the Heater Boiler and ORC Subsystem Tests deals with miscellaneous tests of this subsytem.

\subsubsection{Boiler Piping Steady-State Losses}

TEST OBJECTIVE: To measure the thermal losses the boiler field piping, pumps, and plumbing.

TEST DESCRIPTION: Steady-state losses of the boiler system add to the total thermal losses of the solar system. The boiler system begins at the high temperature storage tank and continues through the boiler pump and through the hoiler (heat exchanger). After exit from the boiler, fluid is returned to the bottom of the high-temperature storage tank. The piping is insulated to reduce heat loss, however, there is a large thermal gradient between the fluid transferred through the piping and the ambient air, so there is a thermal loss through the insulation. Several valves control the system that also cause thermal losses. The pumps are not well insulated because of their accessibility for maintenance, causing another thermal loss. If the total heat loss through the system is significant compared to the energy collected by the collectors, overall system efficiency will be reduced proportionally. Thus it may be necessary to install additional insulation at valves, pumps, and field piping.

TEST CONDITIONS: To conduct this test, the storage tank will be full of $590^{\circ} \mathrm{F}$ fluid. This fluid will tlien be clrculated through the boiler until steady-state conditions are reached. With the input temperature constant, and the thermal mass losses of the system overcome, the output temperature should also be constant. There are thermocouples throughout the system so that isolated losses can be determined for components such as pump losses or boiler losses. Therefore, the total loss of the system, as well as isolated losses of the critical items, can be determined.

This test can be conducted with the ORC (turbine) system either on or off. With the tilrhine operating, the fluid returned from the boiler to the storage tank will be $470^{\circ} \mathrm{F}$. The temperature of the fluid with the turbine not operating should be close to the input temperature of $590^{\circ} \mathrm{F}$. The heat loss of both conditions will be determined.

DATA REQUIREMENTS: The data required will be all on the minicomputer printout. The thermucuuple readouts, the flow rates and speciflc heats will provide all the necessary data. 


\subsubsection{Boiler Thermal Mass}

TEST OBJECTIVE: To determine the thermal mass (total heat capacity) of the ORC boiler and associated piping.

TEST DFISCRIPTION: To measure the total heat capacity of the ORC boiler and associated plumbing, the system shall be allowed to reach equilibrium with local ambient temperatures.

Then hot fluid will be injected and circulated through the system. The total flow and temperatures recorded by all thermocouples in the boiler cycle shall be recorded as steady-state where equilibrium is achieved. (The thermal mass of the boiler system is that amount of heat required from the oil to aohiove steady-state conditions.) During this test toluene will be drained from the boiler so that the heat will be absorbed from the fluid only by the boller itself and ito aceociated piping.

TEST CONDITIONS: There are no environmental requirements for this test. The boiler and associated plping shall be allowed to reach ambient temperatures. This shall be done by not circulating oil through the boiler for a minimum of two days prior to the test. It. is required that the data-acquisition system and the thermocouples in the boiler cycle be operating properly and that the boiler be drained of toluene.

DATA REQUIREMENTS: The data required from this test include:

1. Fluid temperature at boiler input.

2. Fluid temperature at boiler output.

3. Fluid flow rate.

\subsubsection{Pumping Losses}

TEST OBJECTIVE: To measure power-requirement-in versus work-out of the boiler-fluid transfer pump and the fluid-pressure-drop through the boiler and associated plping.

TEST DESCIIPTION: Pressure gauges shall be attached with shut-off hand-valves at the input and output of the boiler fluid transfer pump. A watt-hour metcr shall be connected to the pump motor. In the course of a typical sunny day, during which solir energy is bcing collected and fluid is being circulated through the boiler, the differential piessurc, tho total pusip flnw, and the power consumption shall be monitured.

TEST CONDITIONS: This test must be performed on a reasonably clear (not more than $10 \%$ cloud cover) day during which solar encrgy is being collected and the solar tracking system is functioning properly. If the total heat capacity of the storage tank is exceeded (and fluid temperatures need to be lowered), the ORC or the cooling tower shall be utilized to lower fluid temperatures within tolerance. 
DATA REQUIREMENTS: The data required from this test include the differential pressure through the pump, the total fluid flow through the pump, and the power consumed by the pump. The temperatures recorded by the thermocouples in the boiler, the hot fluid storage tank, and all the associated piping shall be. recorded during that period when hot fluid is replacing cold fluid in the system prior to steady-state conditions being achieved. The output of the boiler-oil transfer pump flow meter shall also be recorded during this period. 


\section{CONDENSER AND COOLING-WATER FLUID HANDLING SUBSYSTEM}

\subsection{Maximum Heat Removal}

This section of the Condenser and Cooling-Water Fluid Handling Subsystem Tests deals with maximum heat removal of the subsystem.

TEST OBJECTIVE: To evaluate the condenser nuld/luwer watcr hual exchangr.r for maximur heat-load conditions. These heat-load conditions occur with the condenser water at $88^{\circ} \mathrm{C}\left(190^{\circ} \mathrm{F}\right)$ inlet temperature to the heat exchanger and $77^{\circ} \mathrm{C}\left(170^{\circ} \mathrm{F}\right)$ outlet.

TEST DFSCRIPTION: The condenser liquid/tower water heat exchanger was sized for a $\mathrm{mini}$ mum $\Delta \mathrm{T}$ between the cooling waler and the condenser water. These conditions will exist at equinox operation. The unit is sized for $527,000 \mathrm{~kJ} / \mathrm{hr}(500,000 \mathrm{Btu} / \mathrm{hr})$; the current requirement is for approximately $608,000 \mathrm{~kJ} / \mathrm{hr}(577,000 \mathrm{Btu} / \mathrm{hr})$, as reported in the "Solar Tolal Energy Rrogram Semiannual Report of April 1975 - September 1975. " The increased requirement can be met by opcrating when the dew point is below $29^{\circ} \mathrm{C}\left(85^{\circ} \mathrm{F}\right)$, or by increasing tower water flow rate. The pump capacity has been increased and should provide sufficient flow to meet the increased requirements. The capability of the heat exchanger to meet the requirements with this liew flow will be tested. The cooling tower pump may not have sufficient capacity to handlc the increased flow rate to the turbine-load heat exchanger. Il will be teatod to dotermint ils capacity.

Control valve V10 regulates the flow of condenser water through the hcat exchanger. When steady-state conditions exist, V10 will be checked to determine if it is completely or partially open. If it is open, the system will be neár lts maximum capability. If it is nartially closed, the system has some additional capability. If the latter is the case, the valve will be opened manually and the ensuing conditions will be monitored. This should provide information on the maximum capability of the system.

TEST CONDILIUNS: The lurbine/Ulë oyetusu will he opcrated using the fossil-fuel heater. This will allow stabilized conditions to be established. The condenser water loop will be adjusted to an input of $190^{\circ} \mathrm{F}\left(88^{\circ} \mathrm{C}\right)$ and an output of $170^{\circ} \mathrm{F}\left(77^{\circ} \mathrm{C}\right)$ with an electrical load of $32 \mathrm{~kW}$. The water tower inlet temperature to the heat exchanger will be set at $85^{\circ} \mathrm{F}\left(29^{\circ} \mathrm{C}\right)$.

DATA REQUIREMENTS: The minicomputer printouts, digital readouts, and strip charts will be monitored and recorded to evaluate the system's capability to maintain conditions. 
DISTRIBUTION:

TID-4500-R65, UC-62 (298)

American Gas Association

1515 Wilson Boulevard

Arlington, VA 22209

Attn: P. Susey

Argonne National Laboratory (2)

9700 South Cass Ave.

Argonne, IL 60439

Attn: M. L. Kyle Office of the Director

S. Zwerdling Director of Solar Energy Programs

Battele Memorial Institute

Pacific Northwest Laboratory

P. O. Box 999

Richland, WA 99352

Attn: K. Drumheller

Brookhaven National Laboratory

Associated Universities, Inc.

Upton, LI, NY 11973

Attn: J. Blewett

University of Delaware

Institute of Energy Conversion

Newark, DE 19711

Attn: K. W. Boer

Edison Electric Institute

90 Park Avenue

New York, NY 10016

Attn: L. O. Elsaesser

Director of Research

US Energy Research and Development Adm. (15) Solar Energy Division

20 Massachusetts Ave.

Washington, DC 20545

Attn: H. Marviúı

R. Blieden

G. Kaplan (10)

S. Gronich

J. Rannels

L. McLamed

US Energy Research and Development Adm. (5) Albunierque Operations Office

P. O. Box 5400

Albuquerque, NM 87115

Attn: D. L. Krenz

D. K. Nowlin (3)

J. R. Roder

Envirodynamics, Inc.

3700 McKinney Ave.

Dallas, TX 75204

Attri: J. E. Guthrie
Energy Institute

1700 Las Lomas

Albuquerque, NM 87131

Attn: T. T. Shishman

Environmental Factors and Public Utilities Div. Department of Housing and Urban Development Washington, DC 20410

Attn: A. R. Siegel, Director

University of Idaho

Moscow, ID 83843

Attn: H. Silha

Deputy to the Science Advisor

U. S. Department of Interior

Room 5204

Washington, DC 20240

Attn: M. Prochnik

Intertechnology Corporation

Box 340

Warrenton, VA 22186

Attn: G. C. Szego, President

Lone Star Gas Company

901 S. Harwood St.

Dallas, TX 75201

Attn: L. H. Sutherland

University of California

Lawrence Livermore Laboratory

P. O. Box 808

Livermore, CA 94550

Attn: W. C. Dickinson

Congressional Research Service

Library of Congress

Washington, DC 20540

Attn: H. Bullis

Srienre Polioy Division

Midwest Research Institute

425 Volker Blvd.

Kansas City, MO 64110

Attn: J. O. Bradley

New Mexico State University

Las Cruces, NM 88003

Attn: R. L.' San Martin

University of New Mexico

Department of Mechanical Engineering

Albuquerque, NM 87106

Attn: W. A. Cross

For: M. W. Wilden 
Northern Natural Gas Co.

2223 Dodge St.

Omaha, NB 68102

Attn: J. M. De La Castro

Oak Ridgc National I_aboratory (2)

P. O. Box $Y$

Oak Ridge, TN 37830

Attn: J. Johnson

R. Pearlstein

Office of Stclence and Technology

Txecutive Office of the President

Washington, DC 20506

Attn: R. Balzhizer

Office of Technology Assessment

Old Immigration Building, Rm 722

119 D. Street, NF

Washington, DC 20002

Attn: R. Larsen

Jet Propulsion Laboratory

Bldg 277 Rm 201

4800 Oak Grove Dr.

Pasadena, CA 91103

Attn: V. C. Truscello

Omaha Public Power District

1623 Harney

Omaha, NB 68102

Ațtn: A. R. Spanglor

The Pentagon

Room 3E114, IVail Stop 103

Washington, DC 20545

Attn: G. Norough

Deputy Director for Research and Advanced Technology

Raytheon, Inc.

Missile System Division

Spencer Laboratories

Wayside Avenue

Buslington, MA 01803

Attn; L. Paradis

Southern California Gas Co.

P. O. Box 3249

Terminal Annex

Los Angeles, CA 90051

Attn: S. C.omningham

Southern Union Gas Company

Fidelity Union Tower Building

Room 1537

1507 Pacific Avenue

Dallas, TX 75201

Attn: J. O. Carnes
Gas Company

723 Silver SW

Albuquerque, NM 87103

Attn: B. D. Daugherty

Sundstrand Electric Power

4747 Harrison Avenue

Rockford, IL 61101

Attn: A. W. Adam

Carroll V. Kroeger, Sr.

Director, Tennessee Energy Office

Suite 250

Capitol Hill Rlilg.

Nashville, TN 37219

Watt Engineering Ltd

RR 1, Box $1831 / 2$

Cedaredge, CO 81413

Attn: A. D. Watt

Texas Electric Service Co.

P. O. Box 970

Fort Worth, TX 76101

Attn: J. A. Harris

Marketing Services Manager

W. G. Newton

General Manager

South Plains Electrric Coop. Inc.

P. O. Drawer 1830

Lubbock, TX 79408

IVlessr Bermard Devin

Chef de Projet Solaire

Cen Saclay

B. P. No. 2

91190 GIF SUF YVETTE

Larry Smith

HLO Smith

ICI

United States Inc.

P. O. Box 6008

Chatanooga, TN 37401

Sua Hutchison

Solar Kinetics Inc.

147 Parkhouse St.

P. O. Box 10764

Dalla.s, TX 75207

Gerald Kal's

8116 Appleton Ave.

Milwaukee, WI 53218

Del Manufacturing Co.

905 Monterey Pass Road

Monterey Park, CA 91754

$\Lambda$ ttn: M. M. Delgado 
DISTRIBUTION (Cont.):

Soltrax, Inc.

720 Rankin Rd., NE

Albuquerque, NM 87107

Attn: C. A. Coonce

Vice President, Research

Honorable Manuel Lujan, Jr.

1323 Longworth Building

Washington, DC 20515

Honorable Harold Runnels

1535 Longworth Building

Washington, DC 20515

Honorable Pete V. Domenici

4103 New Senate Building

Washington, DC 20510

Honorable Harrison H. Schmitt 1909 Wyoming $\mathrm{NE}$

Albuquerque, NM 87112

Richard Waterman

Solar Intel

P. O. Box 38

Riverton, CT 06065

Steve Tipaldi

General Delivery Capitala

Capitala, CA 95060

Pat Lynch

318 Rackley Bldg.

Pennsylvania State University

University Park, PA 16802

Mitchell Knight

372 Bluff View Drive

Largo, FL 33540

D. J. McCann

Energy Research Center

Department of Chemical Engineering

University of Sydney

Australia 2006

Krishan D. Mannan

Head, Mech. Eng. Dept.

College of Agricultural Eng.

Punjab Agricultural University

Ludhiana, Punjab, INDIA

Bill Laughran

Hi G Research \& Eng.

244 Woodland Avenue

Bloomfield, CT 06002
Ed Diamond

Manager, Advanced Concepts

Grumman Corporation

4175 Veterans Memorial Highway

Ronkonkoma, NY 11779

A. J. Poche

General Electric Co.

P. O. Box 8661

Philadelphia, PA 19101

B. P. Gopta

MS MNI7-T789

Honeywell, Inc.

2600 Ridgeway Parkway

Minneapolis, MN 55113

Darwin Vexler

Chemical Projects Associates, Inc.

30 Rockefeller Plaza

New York, NY 10020

Commanding General

White Sands Missile Range, NM 88002

Attn: STEWS-TE-NT

M. Squires

1100

C. D. Broyles

Attn: J. D. Kennedy, 1110

G. E. Hansche, 1120

1262 H. C. Hardee

1280 T. B. Lane

1284 R. T. Othmer

1300 D. B. Shuster

1330 R. C. Maydew

1333 S. McAlees, Jr.

1400 A. Y. Pope

2300 L. D. Smith

2320 K. L. Gillespie

Attn: C. M. Gabriel, 2323

L. W. Buliulz, 2324

2530 M. K. Parsons

2541 G. W. Cobeli

3700 L. S. Conterno

3720 L. E. Fuller (3)

Attn: E. G. Dylo, 3721

5000 A. Narath Attn: J. K. Galt, 5100

5110 F. L. Vook

5130 G. A. Samara

5150 J. E. Schirber

5200 E. H. Beckner

5231 J. H. Renken

5420 J. V. Walker

5700 J. H. Scott

5710 G. E. Brandvold 
DISTRIBUTION (Cont.):

5712 J. A. Leonard (200)

5713 J. V. Otts

5714 R. P. Stromberg

5715 R. H. Braasch

5719 D. G. Schueler

5730 H. M. Stoller

5735 M. M. Newsom

5740 V. L. Dugan

5800 R. S. Claassen

Attn: R. L. Schwoebel, 5820

5830 M. J. Davis Attn: D. M. Mattox, 5831

5840 H. J. Saxton Attn: J. N. Sweet, 5842

F. P. Gerstle, 5844

E. K. Beauchamp, 5846

8100 L. Gutierrez

8132 A. C. Skinrood

8180 C. S. Selvage

8313 R. W. Mar Attn: T. T. Bramlette, 8313

9300 L. A. Hopkins, Jr.

9330 A. J. Clark, Jr.

9340 W. E. Caldes Attn: J. L. Mortley, 9344

9400 H. E. Lenander

9410 R. L. Brin Attn: R. K. Petersen, 8412

9515 J. T. Hillman

9700 R. E. Hopper Attn: H. H. Pastorius, 9740

M. H. Wempe

G. C. Newlin

E. A. Aas (2)

3141 C. A. Pepmueller (Actg) (5)

3151 W. L. Garner (3) For ERDA/TIC (Unlimited Release) 